\title{
Credit Market Discipline and Capitalist Slavery in Antebellum South Carolina
}

\section{John J. Clegg}

\begin{abstract}
Historians and economists have increasingly identified capitalist patterns of behavior among antebellum slave owners, yet no consensus has emerged about the explanation for this finding. I argue that US slave owners were driven to behave like capitalists in part because of their dependence on credit. The ability of creditors to seize the land and slaves of insolvent debtors generated selection pressures that led to both aggregate patterns of capitalist development and the adaptation of individual slave owners to the logic of capitalist competition. I refer to this process as "credit market discipline." In a case study of South Carolina in the 1840s, I show that the threat and reality of foreclosure was capable of stimulating recognizably capitalist behaviors among even the most aristocratic and "prebourgeois" slave owners.
\end{abstract}

In 1823, at the nadir of the first major downturn in the cotton market, cotton was selling at less than 10 cents a pound in South Carolina, then the center of cotton cultivation in the United States. Hezekiah Niles, editor of Niles' Register, a leading business paper of the day, had predicted that cultivation would be reduced when the price fell beneath 10 cents, for at any lower price cotton would be "unworthy of the attention of the capitalist, if he has the power to turn his capital to almost anything else" (Niles 1822: 216). Yet the price stayed below 10 cents a pound for most of the remaining years before the Civil War, and South Carolina steadily increased its cotton cultivation in those four decades.

In 1841, in the midst of the next major cotton downturn, with South Carolina facing stiff competition from the new cotton states of the Southwest, Governor J. H. Hammond reported his calculations of the cost of cotton production to the State Agricultural Society. In his address, Hammond recommended that South Carolina planters switch to growing food, for he claimed that "cotton cannot be profitably grown here at 8 cents per lb." (Hammond 1841: 180). Yet the price remained below 8 cents for all but one year of the 1840s, and cotton production in South Carolina almost doubled over that time.

That the lower prices resulted in South Carolina planters producing more rather than less cotton not only presents a puzzle for standard economic theory, but may also come as a surprise to those familiar with the literature on the history of American slavery. Writing in the 1960s, both the Marxist historian Eugene Genovese (1965:

I am grateful to Robert Brenner, Vivek Chibber, Stanley Engerman, Duncan Foley, Ann Morning, Suresh Naidu, Michelle O'Brien, Deidre Royster, Nathan Tankus, Chris Seeds, two anonymous referees, and to participants in New York University's Economic and Political Sociology workshop and the New York Market Cultures Group, whose suggestions greatly improved this article (while all remaining errors are my own). Thanks to Richard Steckel and Nicolas Ziebarth for generously sharing their data. Especial thanks to Bonnie Martin, Lindsay Keiter, and the staff of South Carolina Archives and History for helping a sociologist discover the archive. 
298) and the neoclassical economist Douglass North (1966: 72, 129-30) described how planters in the Old South withdrew from the market when prices fell, planting less cotton and more subsistence crops, much as Hammond had recommended. For Genovese (1965: 19-23) this was a symptom of the South's "precapitalist" mode of production. He argued that the planters' quasifeudal values of landed independence encouraged them to insulate themselves from the market (ibid.: 31, xxiii). For North (1966: 71), by contrast, it was simply a "rational redirection of resources during periods of depressed prices." Yet the evidence from South Carolina suggests that both authors were mistaken, for planters there increased their production of cotton as prices fell, a behavior that economists sometimes refer to as "perverse supply response" (Ozanne 1999).

In this article, I attribute this "perversity" to an effect of credit markets and debt enforcement on, first, the choice of crop, and second, the productivity of plantations. I focus on the depression of the 1840s, when new Southwestern supplies kept cotton prices low, wiping out profit margins for many South Carolina plantations. Although the price of corn also fell during this period, planters could still have saved on food purchases by planting more subsistence crops, as Hammond had advised. However, most plantations purchased their inputs on credit, and many had accumulated longterm debt by mortgaging land and slaves. The need to repay these debts prevented plantations from taking up Hammond's advice and becoming more self-sufficient, for as prices fell they had to plant more of the cash crop to meet these fixed monetary commitments. ${ }^{1}$

I argue that cotton specialization was a short-term solution to a problem of cash flows, but a virtual doubling of cotton output over a decade cannot be attributed to specialization alone. Instead, I argue that in the long run more cotton was grown, despite continued low prices, because South Carolina plantations were ultimately able to recover their profit margins by increasing productivity—-through introducing new techniques and varieties, and expanding their scale of operations. Despite their "premodern" sympathies, South Carolina slave owners responded to competition in a quintessentially capitalist manner-by specialization, innovation, and adaptationbecause they were dependent on credit, and therefore on markets, to preserve their status as slave owners. I refer to the pressures generated by debt and its enforcement as "credit market discipline."

The article proceeds as follows. In the next section, I review the literature on economic growth under slavery, relating my findings to new developments in the field. I then define credit market discipline and identify its key historical precondition: the ability of creditors to seize the assets of insolvent debtors. I provide evidence, in the third section, of the buildup of debt in South Carolina and the wave of foreclosures that swept the state in the 1840s. In section five, I trace the impact of this crisis on cotton production in South Carolina. I then briefly contrast South Carolina with

1. The simultaneous fall in the prices of South Carolina's other key cash crops, tobacco and rice, also limited the alternatives available to planters. However, a lack of substitute cash crops cannot explain why plantations didn't plant more subsistence crops, as Hammond recommended. 
Kentucky, where I claim that a legacy of debt relief helped to insulate slave owners from credit market discipline. Finally, I conclude by relating my findings to debates on the capitalist nature of antebellum slavery.

\section{Reviewing the Literature on Slavery and Capitalism}

Early studies of the slave plantation assumed that it changed little over time. The typical explanation was that slave owners valued independence over profitability, and that slaves had no incentive to work hard or innovate (Cairnes 1862; Genovese 1965; Phillips 1918). These claims were overturned in the 1960s and 1970s by economic historians who found that slave ownership was profitable (Conrad and Meyer 1958), and that Southern plantations were more efficient than Northern farms (Fogel and Engerman 1975). At the same time, new estimates of gross domestic product showed that incomes in the antebellum South were growing as fast, if not faster, than those in the North. ${ }^{2}$ Yet these studies tended to focus on the level of income, and most attributed change to the migration of slavery to more fertile Southwestern soils, such that the image of the static plantation was by and large preserved.

Of course, all parties recognized one big productivity-enhancing change: the saw gin patented by Eli Whitney in 1794. However, the labor bottleneck on cotton plantations subsequently shifted from ginning to picking, an activity that remained entirely manual well into the twentieth century. The lack of further mechanization reinforced the static view of the cotton plantation (Fleisig 1965). Nevertheless, those who analyzed plantation records could observe a significant increase in the amount of cotton picked per slave (Whartenby 1977: 54). Recently, Alan Olmstead and Paul Rhode (2008, 2010) collected a large database of these records. They found that the average amount of cotton that slaves picked in a day rose fourfold from 1800 to 1860 , increasing at an annual rate of 2.3 percent. ${ }^{3}$ By comparison, according Broadberry et al. (2011, table 8) the annual rate of labor productivity growth in textiles in Britain over the same period-during the height of the Industrial Revolution-was only 1.8 percent. ${ }^{4}$ The traditional view of the static plantation was shattered.

Olmstead and Rhode attribute the bulk of this labor productivity growth to biological innovation: breeding cotton varieties that had higher yields and were easier to pick. Edward Baptist (2014) has recently proposed an alternative explanation: New and brutal methods of competitive discipline forced slaves to come up with more

2. Easterlin (1960), using production estimates, found that Southern per capita income was two-thirds of the Northern level in both 1840 and 1860, keeping pace with overall growth. Engerman (1967) revised Easterlin's estimates and found that Southern incomes grew faster. Lindert and Williamson (2016) have recently provided direct income estimates (including slave incomes) which indicate slower Southern per capita growth between 1800 and 1860, but they still find that growth was higher in the South than in the North in the $1850 \mathrm{~s}$.

3. This falls to 1.9 percent when controlling for the westward movement of slavery (Olmstead and Rhode 2008: 1150).

4. The mechanization of northern wheat farming in the late nineteenth century has been estimated to have generated an annualized labor productivity growth of 1.3 percent (Parker and Klein 1966). 
productive methods of picking. Although their assumptions differ, these authors agree that slave owners innovated in response to market competition. Their work is thus in harmony with an emerging consensus view of a "modernizing" and even "capitalist" South (Barnes et al. 2011; Beckert and Rockman 2016), in which cost-cutting innovation was just as rapid and widespread as in the North. New historians have found evidence of systematic reductions in (1) labor costs, as in the mechanization of Louisiana sugar plantations (Follett 2000), (2) transport costs, as in the spread of steamships and railroads through the South (Johnson 2013; Majewski 2011), and (3) transaction costs, as in the financial innovations of Southern banking (Kilbourne 1995, 2006).

However, while this literature provides us with a detailed picture of how antebellum slave owners modernized "the peculiar institution," it rarely addresses the question of why. By bracketing this question historians have tended, perhaps unintentionally, to revive a "consensus history" view of the origins of American capitalism. On this view, capitalism is either the natural outcome of human endeavor freed from the constraints of feudal relations, or the specific heritage of a "protestant spirit" that traveled to the New World on the first ships. Yet this view has been challenged by historians of "the market revolution" in the North (Stokes and Conway 1996), while in the South it must contend with evidence of the "premodern" sympathies of slave owners (Genovese 1965: 3). Even if we find examples of individual slave owners who were ardent modernizers, this alone cannot explain an increase in the average productivity of Southern plantation. For this we need to understand why the broad mass of slave owners, who often extolled a conservative distaste for markets and modernity, adopted the same innovations.

In what follows, I offer an alternative explanation of the capitalist behavior patterns of antebellum slave owners, one that relies on neither a quasinatural profit-maximizing agent, nor a modernizing cultural hegemony. Rather I point out a key constraint-the seizure and sale of the land and slaves of insolvent debtors-that compelled slave owners to compete via markets, whether they wanted to or not.

\section{Origins and Definition of Credit Market Discipline}

In Hyman Minsky's terms, debt tightens the "survival constraint" on capitalist actors (Mehrling 1999: 139). Minsky (1954: 135) shows that while access to liquidity is a condition of daily survival for everyone in a capitalist society, it is a condition that weighs heaviest on debtors, who are contractually committed to make timely payments. In a transitional context where subsistence production is still common, the spread of debt financing will increase the demand for money. If compelled to make fixed money payments on a regular basis, producers will become dependent on markets, for they will have to "sell to survive" (Brenner 2007). Moreover, competition over a limited supply of credit can help enforce competitive behavior among producers because those able to generate higher returns can post more collateral or pay higher rates to bid credit away from less successful producers. Under these circumstances if 
one group of producers finds a way to lower their costs, others will eventually have to follow suit if they want to maintain access to credit, and thereby to the means of production.

However, for this constraint to be binding, and thus for debt dependency to have a determinate effect on the behavior of producers, an additional condition must be met: Those who fail to make payments must be penalized. I call this "credit market discipline." In traditional societies debtors were often penalized through prison or slavery. While these threats provided ample incentives to repay debts, they also restricted the spread of markets. Both removed insolvent producers from direct involvement with the market, and imprisonment provided the creditor with no means to recoup his losses. By contrast foreclosure, the principal modern form of credit market discipline, sequesters not the person of the debtor but his assets. Foreclosure acts as a selection mechanism, reinforcing market dependency. For in addition to threatening indebted asset owners with lamentable consequence of nonpayment, the legal "execution" of debts enables others to bid for their assets at court sales. Thus, even if some producers refuse to specialize and innovate in response to market incentives, the effect of foreclosure will be to generate aggregate patterns of specialization and innovation nonetheless, for it will reallocate their assets to those more willing or able to make the most cost-efficient use of them.

\section{Origins of Credit Market Discipline in the United States}

From today's vantage point it seems obvious that creditors should be able to seize the assets of insolvent debtors to satisfy their claims. However, this ability emerged only during the transition to capitalism, and it first appeared in a British colonial context. In his survey of credit relations in the Atlantic slave colonies, Jacob Price (1991) distinguishes between a "Latin model" of creditor law, which protected the integrity of the estates of insolvent debtors, and an "Anglo-Saxon model," in which even unsecured creditors were given the right to seize land and slaves. According to Price, the Anglo-Saxon model originated in the reaction of British merchants to a number of debt-relief measures passed by colonial parliaments in the early eighteenth century. ${ }^{5}$ To protect their interest merchant creditors petitioned the British Parliament to pass the Debt Recovery Act (DRA) in $1732 .{ }^{6}$ This act made slaves and land in the colonies liable for the satisfaction of debts by defining them as equivalent to personal or chattel property, thereby removing any legal protection of the assets of debtors or their heirs in foreclosure and inheritance proceedings (Price 1992: 82). It also

5. E.g., in 1719 South Carolina passed a law forcing creditors to accept repayment of debt in goods valued at above-market prices. An attempt to pass a similar measure in Jamaica in 1728 was explicitly mentioned in the merchants' petition to the Board of Trade that instigated the DRA (Priest 2006: 424).

6. Known in the United Kingdom as the Colonial Debts Act, its full title made the purpose abundantly clear: "the Act for the More Easy Recovery of Debts in His Majesty's Plantations and Colonies in America." Subsequent acts of Parliament built on this precedent. The Currency Acts of 1751 and 1764 restricted another form of colonial debt relief: paper money. The DRA was also seen as a precedent for the controversial Stamp Act of 1765 (Priest 2006: 438). 
specified that land and slaves could be seized or sold for the repayment of any debt, whether secured or unsecured, according to the local procedures for chattel property (Priest 2006: 389). Because this was typically public auction, the law effectively eradicated the traditional equity right of debtors to redeem mortgaged slaves and land after execution of a legal judgment. ${ }^{7}$

What Price fails to mention is that at the time of its creation the "Anglo-Saxon model" did not exist in the Anglo-Saxon homeland. As Claire Priest (2006) has shown, the merchants who petitioned Parliament were appealing to customary rights in the regulation of commercial debts, rights they had succeeded in extending to many colonies due to their influence on colonial legislatures, but not to rights that any of them held in Britain. A Parliament dominated by landed interests would never have tolerated the DRA in its own backyard. Preserving the integrity of manorial estates was just as important for English landowners as it was for those of Spain, France, and Portugal. Hence in Britain real property was by default exempted from the claims of all unsecured creditors, and at death was transferred to heirs free of such claims. Even creditors secured by mortgages were often prevented from seizing real property, and chancery courts typically gave heirs precedence over secured creditors in inheritance proceedings. British law would not remove its exemptions for real property until a hundred years after the passage of the DRA, in 1833 (ibid.: 338, 424).

The legislative regime imposed by merchants in the colonies thus truly represented a "new world" of creditor-debtor relations. As Priest (ibid.: 390) notes, "[I]n America, the treatment of land as legally equivalent to any other form of chattel in relation to creditor's claims obliterated the division between landed wealth and commercial wealth, and thus between landowners and merchants." ${ }^{8}$ Because it gave creditors more security, the DRA increased the supply of credit and reduced interest rates in the colonies. ${ }^{9}$ This in turn appears to have boosted trade, helping to shift the locus of the transatlantic economy to the British. ${ }^{10}$ In the process vital assets that had previously been protected from the influence of markets-notably land and labor-were transformed into fully alienable commodities. In his Commentaries on

7. The act also allowed British merchants to prove debts and obtain judgments against colonial debtors in British courts. This aspect of the law was particularly vexing to Virginia elites who-always sensitive to violations of their judicial and legislative autonomy - had refused to pass legislation to this effect several years prior to the act.

8. Note that the law increased the security of all creditors because it made all property liable for both secured and unsecured debts, and prevented legislatures from redefining slaves as real property to protect them from creditor claims. Perhaps most importantly, it reduced the risk to creditors of the untimely deaths of their debtors, whose heirs were no longer granted automatic privileges in inheritance proceedings.

9. Menard (1994: 668) claims that the DRA reduced interest rates in Britain's colonies, and he finds a 50 percent increase in mortgages in South Carolina in the 1730s. Priest (2006: 434) claims that the Jamaican legislature reduced the legal maximum interest rate in reaction to the DRA. Coclanis (1989: 105) shows that the legal maximum interest rate in South Carolina fell throughout the eighteenth century. In summarizing the evidence for the Upper South, Marc Egnal (1998: 93) reports that "[s]tatistical series and planter correspondence illustrate the strong growth of credit after the 1740s."

10. The total per capita value of imports to South Carolina doubled in the 1730s (Egnal 1998: 107, figure 6.8), as did the number of slaves imported through Charleston (Menard 1994: 662). The infusion of credit may have helped Charleston become North America's principal port of export by the 1850s (Coclanis 1989: 104; Hancock 1994: 63). 
the Constitution (1833: 128) Joseph Story writes that the effect of the act was to "make land, to some degree, a substitute for money." This was even more true of slaves, whose mobility and versatility as laborers made them a far more liquid asset.

The American Revolution further consolidated credit market discipline in the United States. After suppressing several debtor revolts in the 1780s, most state legislatures and judiciaries reaffirmed the principles of the DRA in the 1790s. ${ }^{11}$ Meanwhile the Constitution explicitly forbade states from passing many forms of debt relief. ${ }^{12}$ Such protections enabled credit to be extended on longer terms, not only by merchants, but also by wealthy individuals, institutional investors, and the state (using land banks) (Martin 2010: 840-46). In the South lending at interest became a habit of planter elites, a way to make use of surplus funds, and part of a longer-term shift from real to paper assets (Blackmar 2012). Woodman (1968: 34) describes how "the security of cotton-grown, growing, and to be grown - served as the basis of an immense credit system in the antebellum south." When planters rolled over debt from one year to the next they typically offered the additional security of mortgages on land or slaves. Historians have tended to view credit relations between planters as a form of patronage, an age-old neighborly custom governed by norms of reciprocity rather than market pressures. ${ }^{13}$ No doubt these aspects of local credit markets persisted. But the growth of mortgage security is indicative of an increasingly impersonal credit system: one in which neighborly trust was either supplemented or substituted by hard collateral.

\section{Case Study: South Carolina in the 1840s}

My hypothesis is that credit market discipline helped to drive capitalist dynamics in the antebellum South. Specifically, I claim that the ability of creditors to seize the land and slaves of insolvent debtors compelled slave owners to specialize for the market and increase productivity. It did so because most slave owners were in debt, and those who failed to repay their debts at the going rate would end up losing their land and slaves, and thus cease to be slave owners. While this form of credit market discipline is built into the legal form of creditor-debtor relations, its effect should be correlated with foreclosure risk. When this risk is high, as when cotton prices were falling, the debt overhang should have induced individual slave owners to raise cash and cut costs by any means necessary. In addition, foreclosure sales

\footnotetext{
11. On South Carolina's own debtor revolt of the 1780s, see Klein (1992). Priest (2006: 443) cites a South Carolina supreme court ruling from 1803 which reaffirms the legal standing of the DRA, while noting that it was "certainly intended for the benefit of the creditor."

12. See the contracts and commerce clause of the Constitution. The revolutionary era also saw the abolition of primogeniture and entail, giving creditors priority over the division of all property (Priest 2015). Many historians have seen this as the foundational act of American property law, but Priest (2006) argues that the DRA was the more radical break from English traditions.

13. Woodman (1968: 64) emphasizes the friendly relation between planters and their factors, writing that for the credit of the latter "custom, tradition and perhaps the word (spoken or implied) of a gentleman provided adequate security" (see also Mann 2002: 8; Martin 2016).
} 
may have reallocated slaves to more productive plantations. Thus, according to my hypothesis, credit market discipline in a period of falling prices should lead planters not to withdraw from markets, as North and Genovese imagined, but to double down on market competition: to specialize in the highest value crop and adopt cost-reducing innovations.

I have chosen South Carolina as my case study for three reasons. First, more data on debt, foreclosure, and slave sales is available for antebellum South Carolina than for any other state. Second, despite a brief experimentation with debt relief in the revolutionary era, nineteenth-century South Carolina is known for being a stalwart enforcer of creditor rights. ${ }^{14}$ It thus represents a clear case of credit market discipline. Third, it allows me to contrast my argument with a competing hypothesis, for South Carolina is in a sense the last place one would expect to find modern marketoriented behavior. As Thomas Russell (1993: 19) points out: "[W]hat marks the Palmetto State's peculiarity in the historiography is its ultraness: ultra-Southern, ultraslave, ultra-aristocratic, ultra-anti-Yankee." If Genovese's view of the "premodern" motivations of slave owners has any basis, it is in South Carolina that we should be able to see its effects.

\section{Credit Expansion in the 1830s}

In the 1830s, an influx of foreign capital and the advent of free banking led to a credit boom across the United States (Knodell 2006; Temin 1969). Comprehensive data on antebellum debt levels is hard to find, but South Carolina kept some of the best records. ${ }^{15}$ Figure 1, showing 4,485 mortgages collateralized by slaves recorded in Charleston from 1776 to 1843 , indicates that the total number of such mortgages was higher in the 1830 s than in any previous decade. ${ }^{16}$ Bonnie Martin's sample of equity mortgages in three South Carolina counties (of which 71 percent listed slaves as collateral) shows that the amount of capital raised by such mortgages doubled from 1821 to 1835 (Martin 2016: 115). The credit expansion was even greater in the upland cotton county of Fairfield, where the value of mortgages increased by 400 percent from 1821 to 1837 (ibid.: 116).

14. South Carolina was unique in denying married women the right to own property, a right that was often used to shield property from a husband's creditors. Even the owners of state-chartered corporations were denied limited liability. Its banks were notoriously conservative, the legislature committed to "sound money," and the state never saw the inflationary "frontier banking" experienced elsewhere (Smith 1958: 216-17).

15. Menard (1994) records the growth of mortgages from 1710 to 1740 , showing that Charleston merchants increasingly came to specialize in extending credit. David Hancock (1994: 70) calculates that from 1748 to 1775 South Carolinians raised around half a million pounds sterling in 3,252 mortgages. In her sample of three South Carolina counties from 1812 to 1860, Bonnie Martin (2010) records 13,980 individual slaves listed in 1,033 mortgages, raising more than 105 million dollars.

16. Most of these mortgages were for more than one slave, some also included land and other goods. Prior to 1858, all South Carolina mortgages were supposed to be recorded in Charleston, but as Martin (2010) points out, traveling to Charleston to record mortgages was an expense many upcountry planters could not afford. Figure 1 displays raw totals; the number of mortgages per white population also steadily increased from 1800. 
250

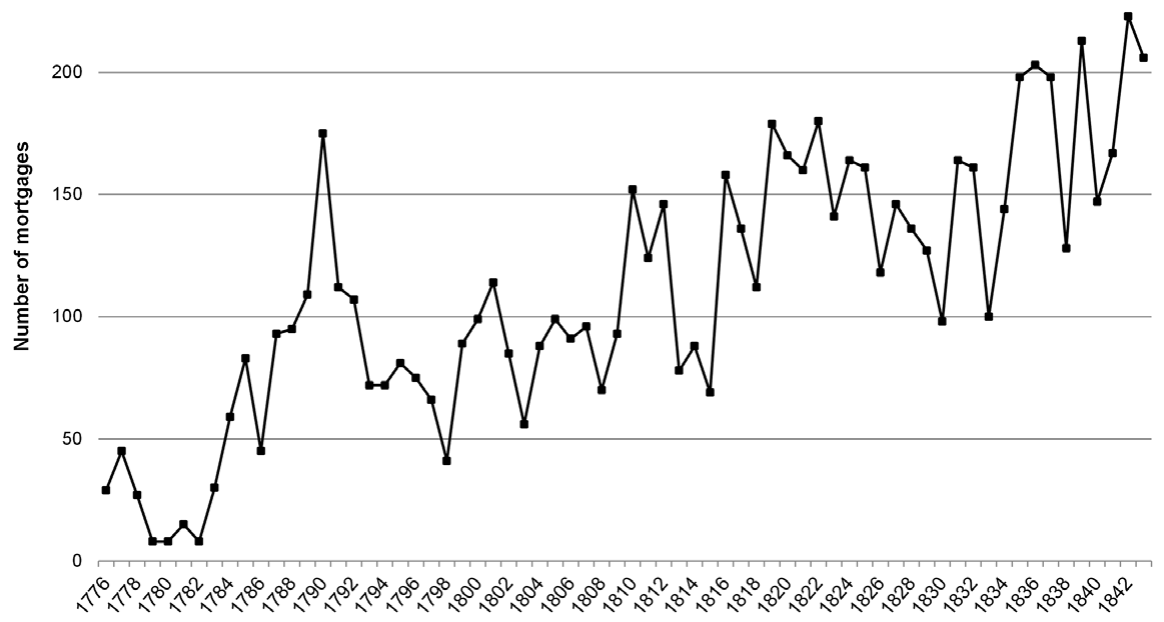

FIGURE 1. Number of slave mortgages in South Carolina, 1776-1843.

Sources: Number of mortgages involving slaves recorded in Charleston: South Carolina Department of Archives and History (SCDAH), Secretary of State, Mortgages (Charleston series) Index (1766-1844).

Bank records provide an alternative snapshot of the 1830 s credit boom. When antebellum banks expanded their balance sheets it was typically to accommodate demand for commercial credit, by discounting notes and bills of exchange (Bodenhorn 2000). Figure 2 displays the average annual assets of South Carolina's five major banks. South Carolina's largest bank, the State Bank of South Carolina, more than doubled its balance sheet in real terms in the 1830s. ${ }^{17}$ The State Bank also significantly extended its proprietary lending against land and slave collateral in the mid-1830s (see figure 3). When many of its borrowers defaulted in the $1840 \mathrm{~s}$, the bank became one of the state's largest owners of slaves. ${ }^{18}$

\section{Foreclosure Crisis in the 1840s}

The "Minsky moment," in which a credit expansion turns to a sudden contraction, came in the panic of 1837. There followed an exceptionally difficult decade for South Carolina's upcountry cotton planters. Prices were depressed at the start of the decade,

17. Although we only have data prior to 1836 for the State Bank, figure 2 suggests other banks expanded their balance sheets even more, for they contracted them to a far greater extent after 1837.

18. The State Bank went from owning $\$ 35,000$ of "real estate and personal property" in May 1838 , to owning \$125,000 in October 1843 (Weber 2011). Fitted neither by charter nor by custom to this role, and facing criticism in the press, the bank drastically reduced direct loans as a percentage of its assets from the mid-1840s onward (Clark 1922; Smith 1958: 197). 


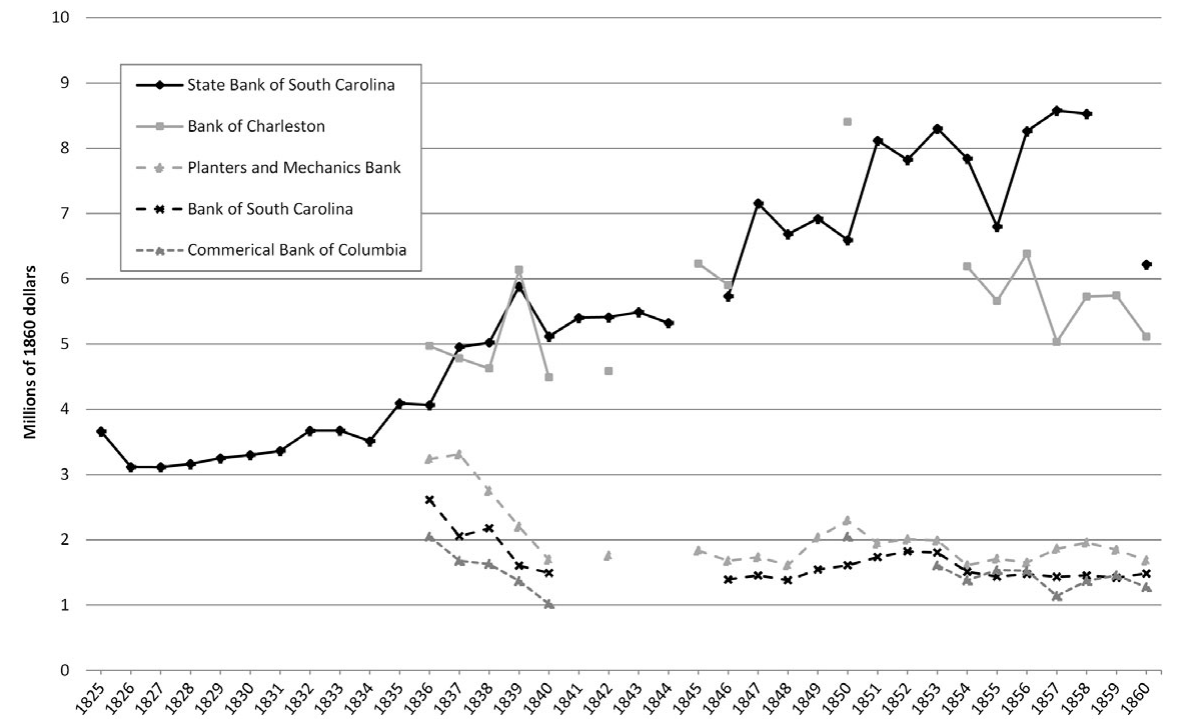

FIGURE 2. Total assets of South Carolina banks, 1825-60.

Source: Average annual assets from Weber (2011), deflated by South Atlantic price index (Margo 2000).

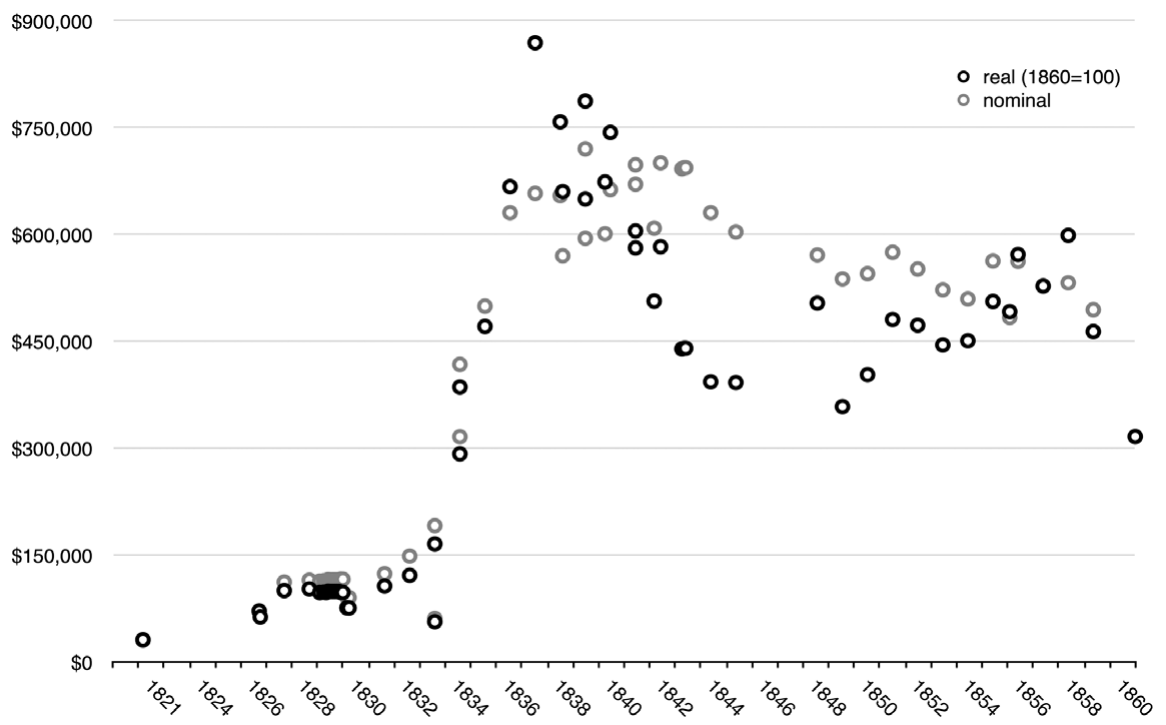

FIGURE 3. Total value of bonds and mortgages held by the State Bank of South Carolina, 1821-60.

Source: Bonds and mortgages from Weber (2011), deflated by South Atlantic price index (Margo 2000). 


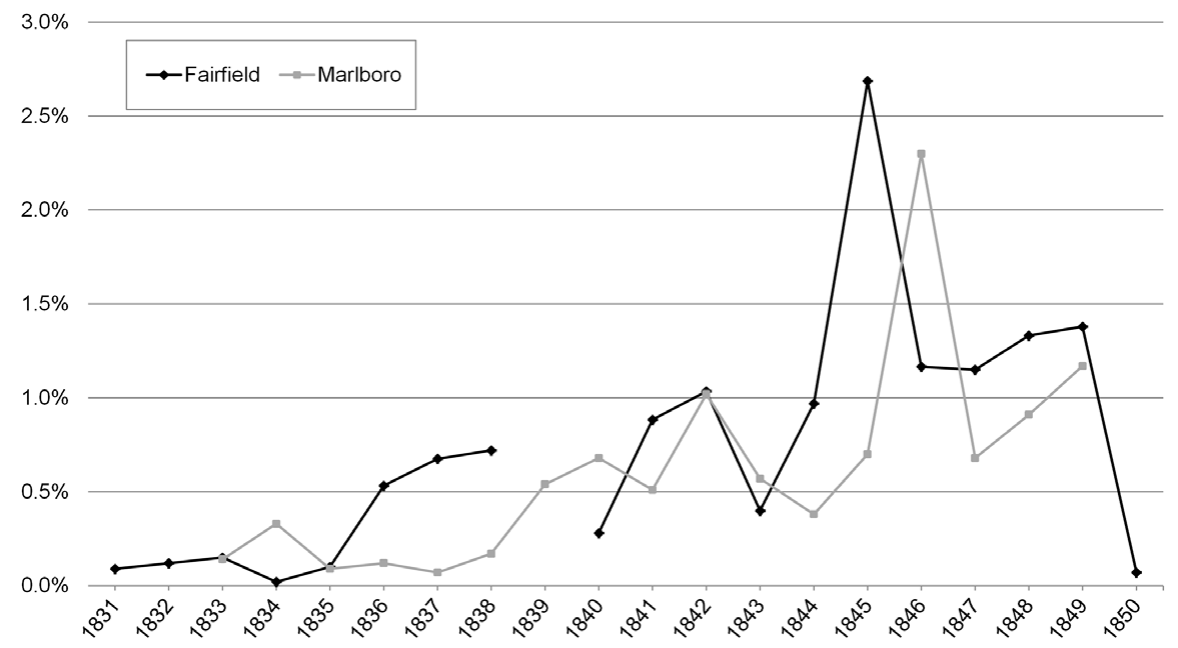

FIGURE 4. Court-ordered slave sales in Fairfield and Marlboro counties, SC, percentage of the slave population sold at auction, 1831-50.

Sources: Russell (1993: 259) and author's own calculations of Fairfield probate and equity sales. SCDAH, Fairfield County: Commissioner of equity sale book 1841-63; Probate Court, sales books 1835-1950.

largely due to a scarcity of money and credit. But the cotton price stayed low due to sluggish economic performance in Britain and increased competition from lower-cost Southwestern cotton producers.

If the sort of credit market discipline I hypothesize were operating in South Carolina we would expect the combination of widespread debt and falling prices to result in a wave of foreclosures as the survival constraint began to kick in. Historians have noted a rise in foreclosure in the 1840s. Lewis Gray (1933: 699) claimed that the low prices "were a source of financial ruin for thousands of planters" in the Old South, while Alfred Glaze Smith (1958: 54) reports that "notices of bankruptcies and assumpsit and capias satisfaciendum proceedings appeared frequently" in South Carolina newspapers. My own analysis of two newspapers finds that the number of such notices approximately doubled. ${ }^{19}$

The most straightforward indicator of the crisis is the number of foreclosure sales. Figure 4 presents the annual percentage of the slave population of two upcountry cotton counties (Fairfield and Marlboro) sold by the courts to repay

19. Edgefield Examiner: notices of capias ad satisfaciendum (arrest of debtors), 4 for 1836-39, 63 for 1840-43, and 141 for 1844-47; notices of assumpsit (suits filed against debtors), 54 for 1836-39 and 72 for 1840-43 (Library of Congress: Historic American Newspapers). Charleston's Southern Patriot: notices of capias ad satisfaciendum, 81 for 1836-39, 167 for 1840-43 (Readex: America's Historical Newspapers). 


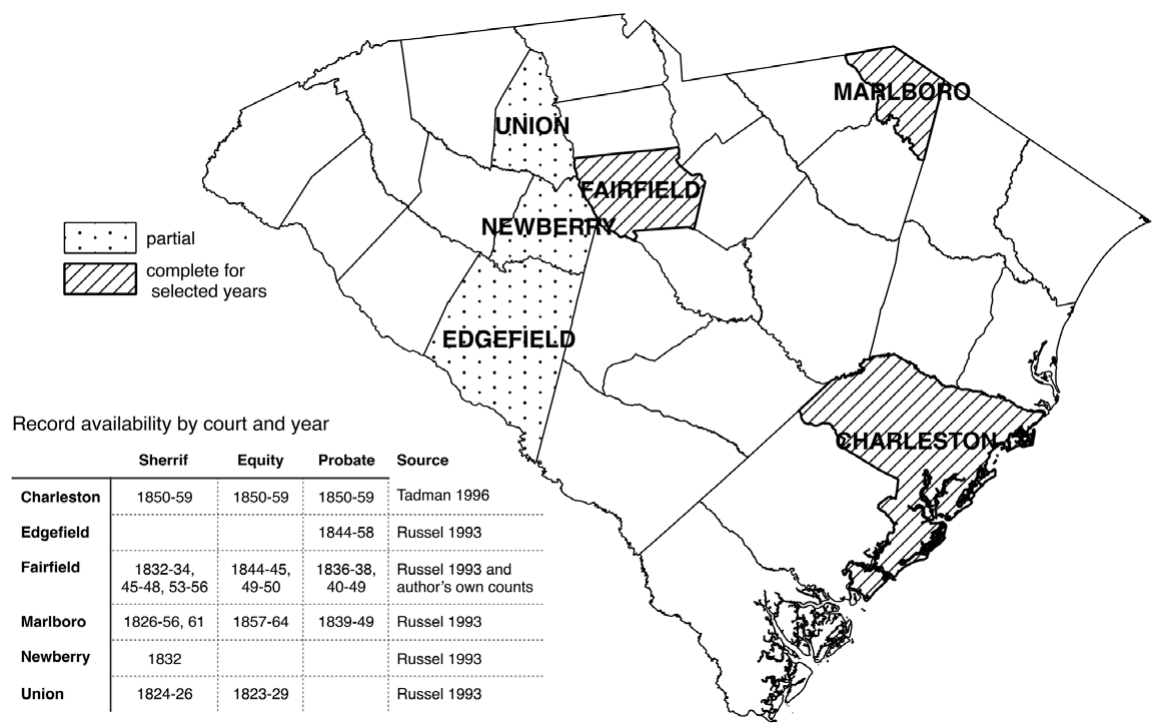

MAP 1. South Carolina counties for which court sale data is available.

creditors. ${ }^{20}$ This figure (representing 2,574 individual sales collected by Thomas Russell and the author) shows that court-ordered sales on behalf of creditors increased significantly during the period of falling cotton prices in the early 1840 s. Mortgages in Fairfield had reached record highs in this period, as creditors demanded more security from their debtors. ${ }^{21}$ When the cotton price bottomed out in 1845 , the same year that a drought drastically cut both corn and cotton yields (Watkins 1908: 80), the number of slaves sold through the courts peaked at 359 , or 2.7 percent of the Fairfield's slave population.

Based on these new estimates of court sales, table 1 presents revised estimates of total slave sales in South Carolina for the three decades following $1830 .{ }^{22}$ It shows that in total 11.5 percent of the slave population in five upcountry cotton counties were sold at auction to repay debt in the 1840s, more than double the number for the decades before and after. Moreover, the majority (56 percent) of slave sales in the 1840s took the form of court sales. By contrast in 2008, at the peak of the recent

20. This figure presents annual sales from the county sheriff, probate court, and equity court for these counties. Records from the other counties in Russell's study (Union, Newberry, and Edgefield) only exist for a subset of years and courts (see inset table in Map 1). I nonetheless draw on data from these counties, as well as Michael Tadman's data from Charleston, in my estimates of decennial court sales in table 1.

21. The author's examination of Fairfield conveyance books 1834-44 revealed that 1844 was a peak year for new mortgage issuance, more than double the average of previous years (SCDAH Fairfield County: Conveyance Books vols. LL-PP). The number of insolvent debtors held in Fairfield's jails also doubled in 1844 (SCDAH Fairfield County: Insolvent debtors' petitions).

22. Table 1 also incorporates Steckel and Ziebarth's data on the coastwise interstate slave trade. See appendix for an account of the methods and assumptions used in calculating these estimates. 
TABLE 1. Revised estimates of slave sales in South Carolina

\begin{tabular}{lccc}
\hline & $1830 s$ & $1840 s$ & $1850 s$ \\
\hline Mean slave population $^{\mathrm{a}}$ & & & \\
Percent of slaves sold at court sales $^{\mathrm{b}}$ & 286,938 & 356,011 & 393,695 \\
Total court sales $_{\text {Total noncourt sales }}^{\mathrm{c}}$ & $5.1 \%$ & $11.5 \%$ & $8.8 \%$ \\
Total sales & 14,633 & 40,941 & 34,829 \\
Total interstate sales $^{\mathrm{d}}$ & 31,825 & 31,394 & 48,983 \\
Percent of slaves sold per year $_{\text {Court sales as a percentage of total sales }}$ & 46,459 & 72,336 & 83,812 \\
Percent of interstate sales from court sales $^{\mathrm{d}}$ & 26,947 & 17,747 & 37,373 \\
& $1.6 \%$ & $2.0 \%$ & $2.1 \%$ \\
& $31.5 \%$ & $56.6 \%$ & $41.6 \%$ \\
\hline
\end{tabular}

${ }^{\mathrm{a}}$ From Tadman (1996).

${ }^{\mathrm{b}}$ From Russell (1993: appendix) updated with Fairfield probate and equity sales.

${ }^{\mathrm{c}}$ Based on two assumptions by Tadman (1996: 120): that 20 percent of court sales went to the interstate trade, and that noncourt local sales were 40 percent of local court sales.

${ }^{\mathrm{d}}$ Slave exports from Tadman (1996: 12), percentage by traders from Steckel and Ziebarth (2013). See appendix for discussion of these estimates.

foreclosure crisis, only 23 percent of all home sales were foreclosures (RealtyTrac 2010).

Together figure 4 and table 1 illustrate what Irving Fisher (1933) has called a crisis of debt deflation: Falling prices increase the burden of debts contracted at fixed interest rates, shifting resources from debtors to creditors. ${ }^{23}$ However, the true extent of credit market discipline is probably underestimated by these data. For every actual court sale, there were presumably many private sales to pay off creditors before having to face the humiliation and costs (in court fees) of a forced public auction. $^{24}$

\section{Consequences: Specialization and Productivity Growth}

Governor Hammond was not alone when he argued, in his address of 1841, that South Carolina planters should restrict their planting of cotton. Letters and editorials in the 1840s were replete with proposals that the state should diversify its agriculture and grow more food crops (Gray 1933: 917; Smith 1958: 72-83). It was hoped that this would boost the price of cotton and reduce dependence on imports of meat and

23. George McDuffie, South Carolina's governor during the credit expansion of the 1830s, identified the risk of debt deflation: "Owing to the periodical fluctuations inseparable from such a system, it has generally happened that a credit obtained by a planter, to the amount of one third of his estate, in a period of expansion, has required the whole estate to redeem it in a period of contraction" (State Agricultural Society 1846: 105).

24. Russell (1993: 183-85) lists the fees that accumulated at each stage of the default process in South Carolina. Priest (2006: 437) notes, "Foreclosure sales are likely to represent only a small percentage of land sold to satisfy creditors' claims," and finds that in colonial Massachusetts court fees on average amounted to 32.6 percent of the value of the debt (1999). 


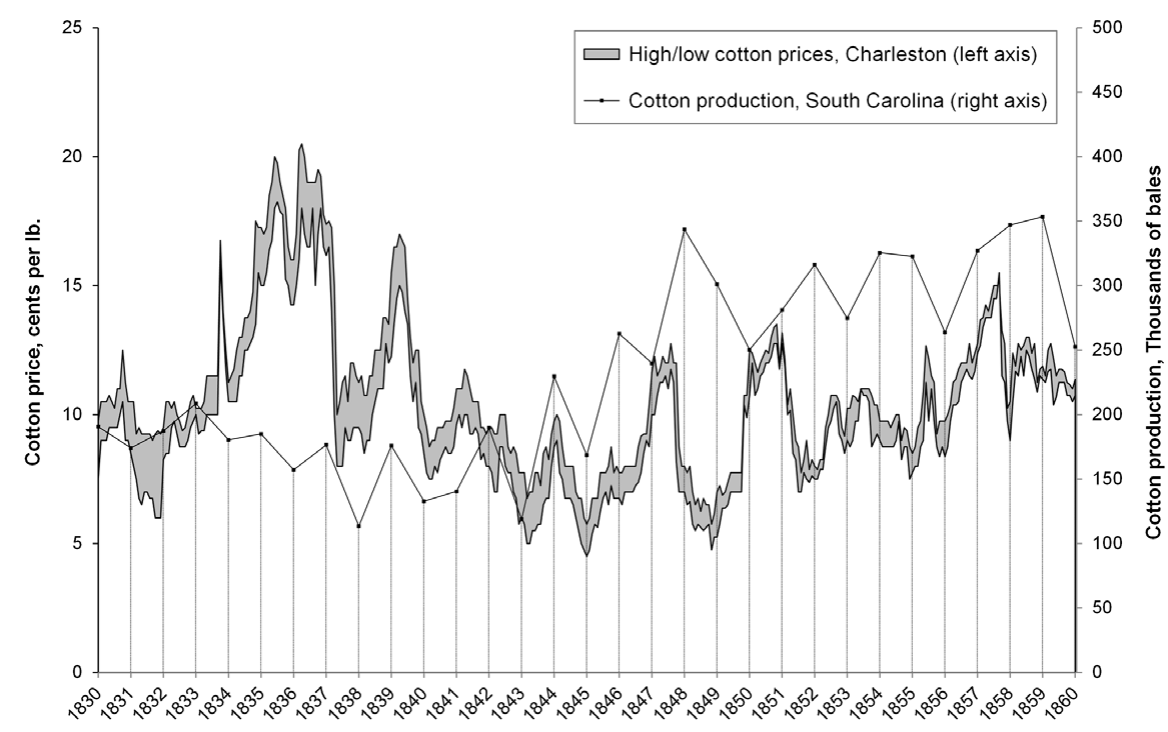

FIGURE 5. Cotton prices and production, South Carolina, 1830-60.

Sources: Cotton output from Watkins (1908: 71-85). Prices from Smith (1958), delated by South Atlantic price index (Margo 2000).

grain, as well as reducing the debt burden of planters. ${ }^{25}$ But while Hammond and others stressed the advantages of independence, they also saw diversification as an inevitability. In the same year as Hammond gave his address to the Agricultural Society, the Patent Office (1841: 75) wrote: "[W]henever ... the price of cotton is low, the attention of cultivators, the next year, is more particularly diverted from cotton to the culture of corn." For Hammond, the reason was obvious: "[W]hen the more valuable crops fail, and the means of purchasing are taken from us, we shall be driven to produce provisions of all kinds" (Hammond 1841: 186).

However, this prediction did not bear out. Figure 5 shows that the state's cotton output rose as the price fell. Total cotton yields almost doubled between the census years. The sharpest rise occurred in 1844, five years before prices began to sustainably recover in 1849 . Thus, the decade with the lowest cotton prices also saw the greatest increase in production.

One possible explanation is that South Carolina planters did the opposite of what Hammond recommended: They became more rather than less specialized in cotton. Figure 6 displays the trend in cotton production alongside South Carolina's two other major staples-corn and rice-as well as an estimate of corn imported from other states through Charleston. It shows that while cotton production followed its upward 

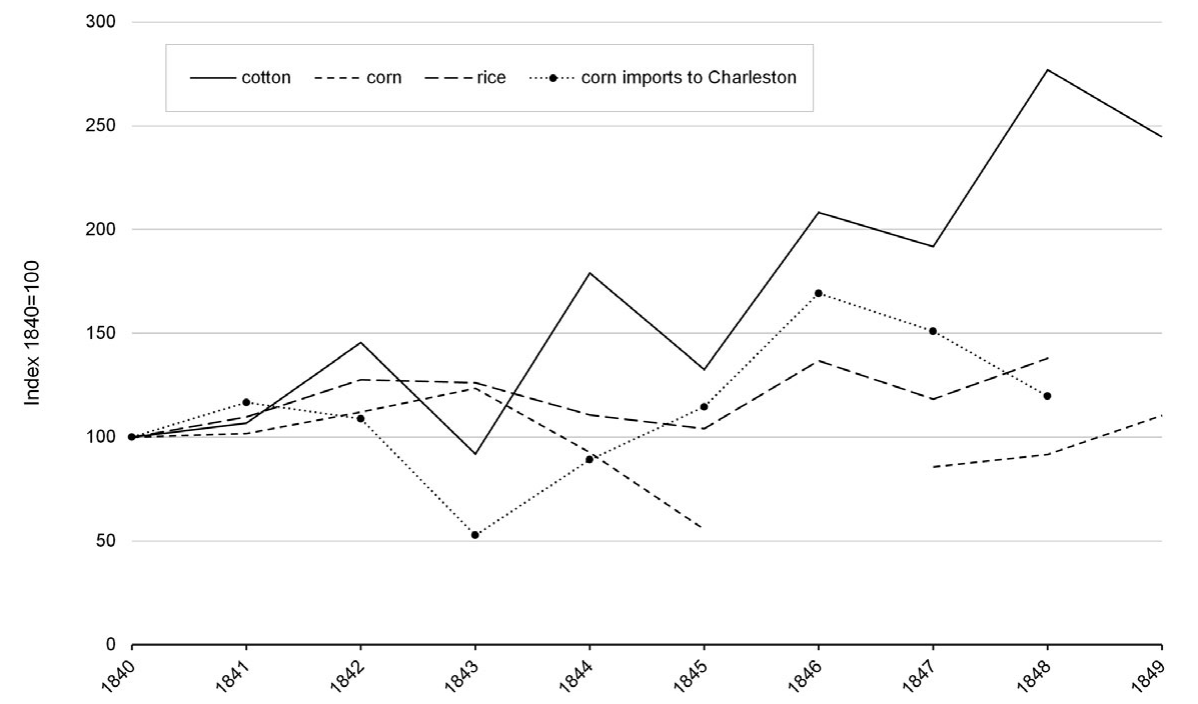

FIGURE 6. Cotton, rice, and corn production, South Carolina, 1840-49.

Sources: Cotton (Watkins 1908: 71-85). Rice and corn (Commissioner of Patents Reports on Agriculture). Corn imports to Charleston (Census of Charleston 1848).

trend, the production of corn and rice fluctuated around a roughly constant level. Corn output peaked in 1843, and cotton output fell, suggesting that planters may have tried to follow Hammond's advice in that year. However, in every other year cotton output grew faster than corn, which declined significantly in the middle of the decade, with corn imports through Charleston rising to compensate. ${ }^{26}$

We can observe this same pattern on Hammond's own plantations. Contrary to the advice he gave planters in 1841, Hammond increased his cotton acreage in that year and the preceding one. While he planted more corn in 1842-43, he returned to his concentration on cotton in 1844-45, the years of lowest cotton prices. Hammond's biographer, Drew Faust (1985: 122), concludes that "despite his dramatic appeal to fellow Carolinians to liberate themselves from the cotton market, Hammond himself remained largely in its thrall." 27

26. Data from the Commissioner of Patents Reports indicate that the output of other food crops tended to fluctuate with the corn crop. Although corn output data is not available for 1846, we know this was a particularly bad year for corn. There were philanthropic efforts in Charleston to send food to the upcountry (Census of Charleston 1848). The Charleston statistics primarily represent urban consumption, but because transportation costs would typically make imported corn more expensive it likely fluctuated inversely with domestic supply.

27. Faust notes that Hammond did shift to corn in the later 1840s, to "decrease his dependence on the widely erratic cotton market." Yet Faust claims that he could do this because he "never developed the pattern of extensive indebtedness that tied many antebellum planters to their cotton factors and thus limited their entrepreneurial flexibility" (1985: 125). 


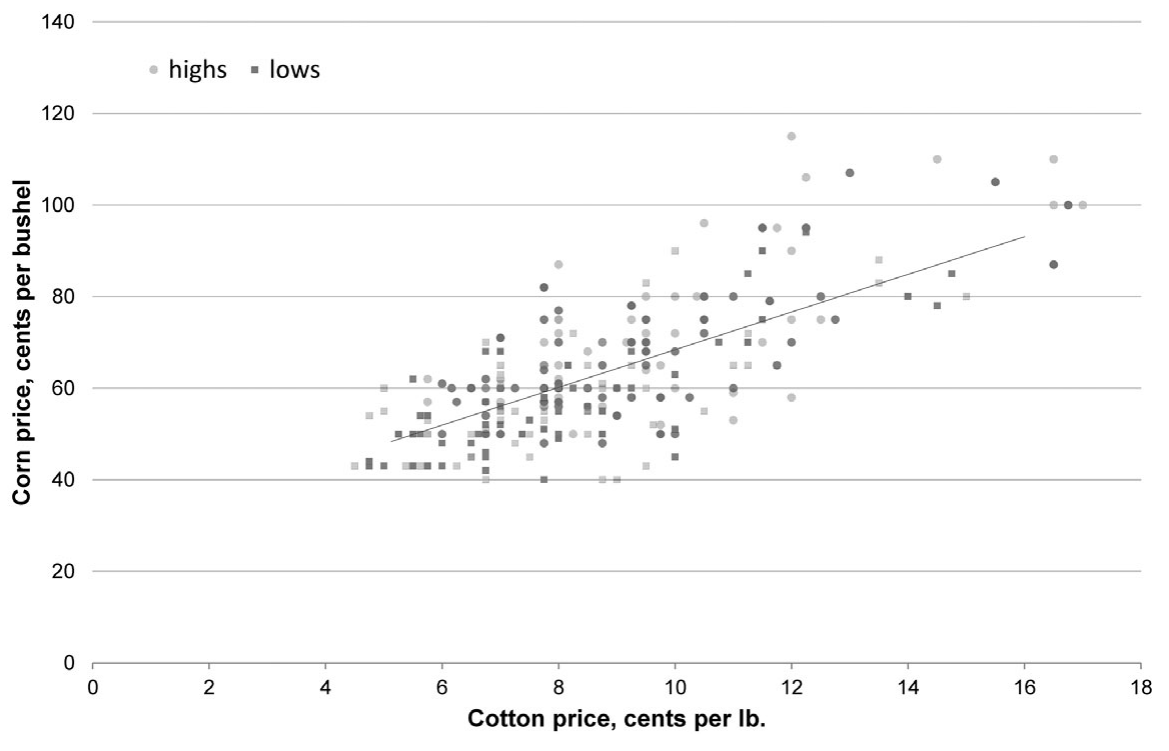

FIGURE 7. Monthly corn and cotton prices, South Carolina 1839-48. Source: Smith 1958.

Economic historians might simply dismiss Hammond's advice as irrational, for two reasons. First, if we overlook consideration of security and risk, and see cropping decisions only in terms of relative prices, then it makes little sense to switch to corn in response to falling cotton prices, for the price of corn also fell in the 1840s. Figure 7 shows the correlation between South Carolina corn and cotton prices. ${ }^{28}$ Second, many economic historians have cast doubt on the trade-off implicit in Hammond's advice, pointing to complementarities between the labor requirements of cotton and corn. They imagine that because labor was typically the scarce factor, planters simply grew as much cotton as their slaves could pick, setting them to work on corn only during lulls in the cotton season. ${ }^{29}$ If this were strictly true it would have been impossible for planters in South Carolina to have produced more cotton in the short run without purchasing extra slaves. We would also expect to find little or no variation in the cotton share of output across farms. However, we know this in fact varied greatly with farm

28. The regression line in figure 7 represents the linear relationship between the mid-points of the high and low monthly prices of corn and cotton in Charleston from January 1839 to January 1849 (Smith 1958). The correlation coefficient is 0.73 .

29. Anderson and Gallman (1977) stress the complementary labor requirements of corn and cotton, yet they recognize that there were periods when work on each crop overlapped (ibid.: 37). They also claim that the introduction of more pickable cotton varieties led to lower corn output, as well as higher labor productivity in corn, suggesting that there were margins of both labor and land along which corn and cotton were substitutes (ibid.: 39). 
size and region. ${ }^{30}$ To solve this puzzle Gavin Wright (2006: 101) has suggested that smaller plantations, confronting constraints of land and credit, followed a "safety first" strategy. The risks of a generally bad corn harvest were double because plantations would face both a shortage of their own supplies and higher prices for purchased corn inputs. Smaller plantations had less collateral with which to mitigate such risks by borrowing, which may explain why "most Southern farms were producing less than capacity levels of cotton output" (Wright 1978: 62).

If Wright's argument is correct then many smaller plantations would be technically capable of planting more cotton. ${ }^{31}$ But why would they do so if (as Wright assumes) they were risk averse? An answer is suggested by South Carolina governor George McDuffie, in an address to the State Agricultural Society in 1840, a year before Hammond's:

\begin{abstract}
One great cause of the incessant struggle to make large cotton crops, to the neglect of every other interest, is the reckless habit of contracting debts. Negroes are purchased upon credit, and the planter is thus furnished both with the means and the motives for unduly and disproportionately enlarging his cotton crop. As cotton is the only crop that will command money, and as money is the most pressing want of a man in debt, everything is directed to that object. (State Agricultural Society 1846: 107)
\end{abstract}

McDuffie's speech suggests that while every planter would benefit from higher prices if others reduced their cotton output, this option was often not available to them individually. The security of corn was only as reliable as the corn harvest, and when both crops failed, as they did in 1845, many planters would have had to take out loans to feed their slaves. ${ }^{32}$ A tightening payment constraint would have made it harder for smaller plantations to roll over existing debts, and compel them to rely more on the cash crop to maintain solvency.

Yet it seems unlikely that an expansion of the internal cotton frontier on smaller plantations could alone have led South Carolina's cotton output to double over the 1840s. The sheer scale of the increase suggests that, in addition to assigning more land and slaves to cotton production, South Carolina's slave owners also found ways to extract more cotton from a given quantity of land and slaves.

Measuring the relative contribution of specialization versus productivity growth to output growth is hampered by an absence of data on how much land was planted in cotton. ${ }^{33}$ We can, however, compare changes in the share of county-level output

30. Using the Parker-Gallman sample from 1860, Wright (2006: 100, figure 3.6) shows that the average cotton share ranged from 39 percent on Southeastern plantations with 1 to 15 slaves, to 76 percent on Southwestern plantations with $90+$ slaves.

31. Wright's argument suggests that larger plantations would already be planting on the extensive margin and would not be able to produce more cotton without purchasing additional slaves.

32. Watkins 1908: 80. The twin crop failure may explain the peak in foreclosure sales in 1845, as well as the sharp rise of slave exports in that year (see appendix).

33. The agricultural census did not even record total farmland for 1840, making it hard to get any sense of the expansion of the cotton frontier over this decade. 
TABLE 2. Cotton shares and labor productivity estimates in upland cotton counties, 1839-49

\begin{tabular}{|c|c|c|c|c|c|c|c|}
\hline & \multicolumn{3}{|c|}{$\begin{array}{l}\text { Cotton share of crop } \\
\text { (1839 prices) }\end{array}$} & \multicolumn{3}{|c|}{$\begin{array}{c}\text { Cotton per } \\
\text { worker (bales) }\end{array}$} & \multirow[b]{2}{*}{ Cotton counties 1839} \\
\hline & 1839 & 1849 & change & 1839 & 1849 & change & \\
\hline Alabama & 0.57 & 0.62 & $8 \%$ & 2.87 & 3.63 & $26 \%$ & 33 \\
\hline Arkansas & 0.57 & 0.68 & $19 \%$ & 3.02 & 3.39 & $12 \%$ & 5 \\
\hline Florida & 0.76 & 0.67 & $-12 \%$ & 3.23 & 3.36 & $4 \%$ & 5 \\
\hline Georgia & 0.65 & 0.59 & $-9 \%$ & 3.91 & 3.12 & $-20 \%$ & 54 \\
\hline Louisiana & 0.67 & 0.26 & $-61 \%$ & 6.06 & 1.46 & $-76 \%$ & 25 \\
\hline Mississippi & 0.78 & 0.65 & $-17 \%$ & 5.40 & 3.15 & $-42 \%$ & 39 \\
\hline North Carolina & 0.41 & 0.18 & $-55 \%$ & 2.10 & 0.64 & $-69 \%$ & 26 \\
\hline South Carolina & 0.52 & 0.62 & $20 \%$ & 1.87 & 2.48 & $32 \%$ & 18 \\
\hline Tennessee & 0.24 & 0.44 & $84 \%$ & 1.56 & 2.70 & $73 \%$ & 13 \\
\hline Virginia & 0.25 & 0.10 & $-60 \%$ & 0.65 & 0.25 & $-62 \%$ & 4 \\
\hline All states & 0.59 & 0.52 & $-19 \%$ & 3.12 & 2.46 & $-21 \%$ & 222 \\
\hline
\end{tabular}

Sources: Agricultural Census (cotton), Craig and Weiss (1998) (labor force). Upland cotton counties are those producing more than 1,000 bales of upland cotton in 1839. Cotton shares calculated at fixed 1839 prices.

to a rough measure of cotton bales per worker. ${ }^{34}$ Table 2 puts both in a comparative context, looking at changes in cotton counties across the South in the 1840s. The first three columns show that while most cotton counties reduced their reliance on cotton in the 1840s, those in South Carolina saw cotton rise from 52 percent to 62 percent of total agricultural output. ${ }^{35}$ The same data (not shown) indicate that these counties also saw a parallel decrease in the corn share, from 35 to 25 percent, even as it increased in most other states.

Although they don't prove that slave owners planted more cotton at the expense of corn, these numbers are consistent with the specialization story. ${ }^{36}$ However, the next three columns of table 2 show that cotton output per slave increased even faster than the cotton share of output, and this too grew faster in South Carolina than in most other states. ${ }^{37}$ These numbers are an inexact measure of slave productivity because we do not know what percentage of the slave labor force produced the cotton, or how many days they worked. However, unambiguous evidence of rising productivity can

34. The latter variable is the total number of bales produced divided by Craig and Weiss's (1998) estimates of the slave labor force in these counties.

35. Cotton shares for 1849 were calculated using 1839 prices to isolate physical quantities. The increase in the cotton share in the 1840s is probably understated in table 2 because 1849 was an above average year for corn and a below average year for cotton (Patent Office 1850; Watkins 1908).

36. The increased cotton share could also be driven by bringing new land under cultivation or by increasing yields on existing cotton lands.

37. The only state to see more growth in productivity was Tennessee, a frontier state that began the 1840s at much lower levels of cotton specialization. The finding of productivity growth is not dependent on the labor force estimate or the census year harvest. If we use instead the total slave population, or three-year averages of Watkins's annual cotton data (1908), productivity growth increases by 50 percent in South Carolina. 


\section{Panel A: Old South $(\mathrm{N}=103)$}

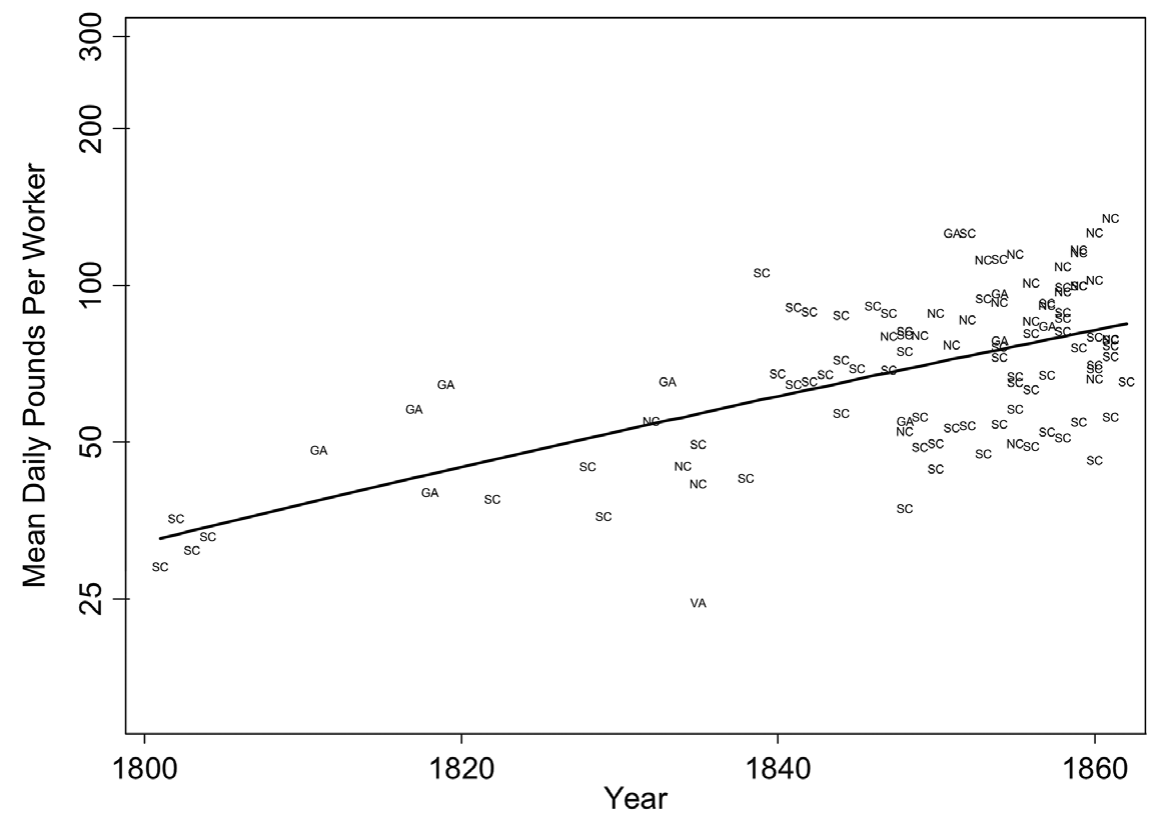

FIGURE 8. Daily cotton-picking rates, Old South, 1800-60.

Source: Olmstead and Rhode 2008: 1158, figure 7A. "Old South" defined as Virginia, North Carolina, South Carolina, and Georgia. Line of best fit is 1.5 percent annual growth.

be found in Olmstead and Rhode's collection of plantation records. Figure 8 shows significant increases in daily rates of cotton picked per slave in the Old South for these years. ${ }^{38}$

While it is difficult to identify empirically the sources of this productivity growth, two possibilities are suggested by the literature: planters may have (1) introduced new, more efficient varieties and techniques, and (2) driven their slaves harder. I will look briefly at both before considering a third possibility: that crisis and foreclosure may have redistributed slaves to more productive plantations.

38. Figure 8 depicts a 15 percent decennial growth in cotton picked per slave. Note that most of this growth appears to have taken place in the early 1840s. By contrast, productivity growth in the New South appears to have slowed in this decade (Olmstead and Rhode 2008: 1155-58). Looking at just the "SC" points in figure 8, it appears that daily cotton picking grew slowly from 1800 to 1840 in South Carolina, from 40 to 50 pounds per slave, then jumped to an average of 80 pounds. However, in correspondence the authors have affirmed that the earlier and later data points are not necessarily from the same plantations or counties and thus should not be read as indicating a precise chronology of productivity growth in South Carolina. 
Under pressure from Southwestern competition, enthusiasm for agricultural innovation swept the South Carolina upcountry in the 1840s. The number of local agricultural societies increased rapidly in the early part of the decade. ${ }^{39}$ They sought to share information about the best varieties and techniques, and published their reports in new journals of scientific agriculture. ${ }^{40}$ Under the aegis of the State Agricultural Society, founded in 1839, they also offered annual awards to planters with the highest yields. In 1840, the society successfully lobbied the legislature to fund an agricultural survey of the state, conducted by the Virginian agricultural reformer Edmund Ruffin. The survey, completed in 1842, uncovered deposits of marl and lime-important fertilizers - and instructed planters on their use. The societies and journals also introduced planters to more efficient methods of ploughing and ginning. ${ }^{41}$ But perhaps the most important technical change of the 1840s was biological in nature.

Olmstead and Rhode $(2008,2010)$ attribute much of the productivity growth they observe to the cultivation of new cotton varieties, such as Petit Gulf, which had higher yields and were easier to pick. These "Mexican hybrids" were first developed in the Southwest, and took longer to adapt to the heavier soils of the upcountry piedmont. Olmstead and Rhode (2010:3) argue this lag explains much of the initial productivity differential between the regions. However, by the end of the 1840s Petit Gulf was the variety most commonly planted in upcountry South Carolina (Watkins 1908: 81). Adapting seeds was a costly business, requiring cooperation among local planters (Olmstead and Rhode 2008: 1134-40), and seeds were a key focus of the journals and agricultural societies in the 1840s. ${ }^{42}$ Olmstead and Rhode attribute the spread of the new cotton varieties to price competition from Western planters, but these pressures would have been muted without the threat of foreclosure.

Historian Edward Baptist (2014: 127, 445) has recently contested Olmstead and Rhode's explanation. He avers that the "ultimate cause" of productivity growth was in fact a system of "calibrated torture" designed to maximize the cotton picked per slave (ibid: 130). In what he calls "the whipping machine," slaves were given individualized daily quotas that were continually increased, and were whipped for failing to meet them (ibid.: 133-42). Baptist's story isn't particularly consistent with the timing and distribution of productivity growth in Olmstead and Rhode's data (Clegg 2015; Olmstead and Rhode 2016) and I have found no evidence that planters treated their slaves more harshly in the $1840 \mathrm{~s} .{ }^{43}$ However, if they did it would not come as

\footnotetext{
39. The number rose from 13 in 1827 to 17 in 1841, 25 in 1842 and 32 in 1847 (Smith 1958: 99).

40. The main such journal was The Southern Agriculturalist, founded in Charleston in 1828. Other journals included Carolina Planter (Columbia, 1840) and The Planter (Columbia, 1843).

41. On the introduction of heavier steel plows and hoes, as well as more efficient horizontal plowing techniques, see Gray (1933: 701) and Smith (1958: 97). On the replacement of the common foot-powered gin with the horse- and later steam-powered McCarthy or Florida gin (patented 1840), see Watkins (1908: 83).
}

42. State Agricultural Society 1846: 147-48. The Southern Agriculturalist discussed seeds in almost every issue. When its editor John Legaré retired in 1842 he went into the seed supply business (Rosengarten 1986: 294).

43. Baptist (2014: 122) points to the degrading effects of "the whipping machine" on infant mortality and adult life expectancy, yet slave mortality in South Carolina appears to have been lower in the 1840s than in the decades before or after. However, it is not clear whether Baptist's argument would be affected by this 
a surprise to Baptist, who claims that "the need to repay loans only accelerated the whipping machine" (ibid.: 271).

It is also possible that some of the productivity increase was due not to any change in the organization of individual plantations, but to a reallocation of land and slaves between plantations. Table 1 indicates that total slave sales increased by 56 percent in the 1840 s, with most of these being court sales. Foreclosures allowed solvent planters to buy up the land and slaves of insolvent debtors at fire sale prices. ${ }^{44}$ This could lead to aggregate productivity growth, either because the highest bidders tended to own plantations that were already more productive, or because the resulting concentration of ownership resulted in economies of scale. ${ }^{45}$

While it is not possible to directly measure the reallocation of land and slaves between plantations, it is possible to get an approximate measure of slave movements and the concentration of slave ownership. ${ }^{46}$ South Carolina's slave population tended to grow more slowly than in most other states, due both to net out-migration and disease vectors in lowland rice-producing counties. ${ }^{47}$ However, table 3 shows that the population in South Carolina's uplands not only grew consistently faster than in the South Atlantic region as whole, but also their rate of population growth doubled in the 1840s. This strongly suggests that slaves were being imported into these counties, either through sales or relocation by planters. Given that the slave population of coastal rice counties declined in the 1840 s, and that the crisis of that decade appears to have been felt hardest in those counties, it is likely that much of the growth in the upland slave population was due to a redistribution of slaves from the rice-producing lowlands, leaving the state more specialized in cotton as result. ${ }^{48}$

One indication that this movement was driven by sales rather than relocation is the increasing concentration of slave ownership in upland counties. ${ }^{49}$ Table 4 shows that

point because he claims that "the whipping machine" was already present on upcountry South Carolina plantations in 1805, and does not give an account of its development over the following decades.

44. The "fire sale" was twofold: Auction prices were typically lower than market prices, and credit constraints forced slave owners to sell when slave prices were low. Because 30 percent of South Carolina mortgages involved land (Martin 2010: 842) we can presume that court auctions of land also increased dramatically in these years. The claim that wealthier or more productive planters were typically the buyers assumes that court auctions were competitive. See appendix for a defense of this claim.

45. Evidence of scale economies on antebellum cotton plantations can be found in agricultural censuses, which show that larger plantations tended to produce more cotton per slave and per acre. There is some dispute about whether these economies were due to the productivity advantage of gang labor (Fogel and Engerman 1975) or to the reduced risk of cotton specialization on larger plantations (Wright 2006). Both explanations are consistent with the account presented here.

46. Unfortunately, it was not possible to provide similar figures for land use or landownership because land use data was not recorded in the 1840 census.

47. Note that Tadman (1996: 12) uses the survivor method to estimate the interstate trade as the difference between state and national-level slave population growth. This method assumes that all states had the same natural rate of population growth, yet South Carolina's lowlands exhibited exceptionally high mortality rates (Coclanis 1989). Thus, Tadman's estimate of net slave exports (reproduced in table 1) should be considered an upper bound.

48. The lowcounty rice economy had been in decline for some time (Coclanis 1989) and falling cotton prices may have hurt Sea Island plantations the most (Porcher and Fick 2005).

49. Governor Adams of South Carolina recognized the tendency for foreclosure to concentrate slave ownership. He argued that slaves should be protected from foreclosure because this would spread slave 
TABLE 3. Slave population growth 1829-59

\begin{tabular}{lrrr}
\hline & $1829-39$ & $1839-49$ & $1849-59$ \\
\hline All South & & & \\
All South Atlantic & $23.8 \%$ & $28.8 \%$ & $23.3 \%$ \\
All South Carolina & $3.6 \%$ & $16.7 \%$ & $10.6 \%$ \\
Upland cotton counties, South Carolina & $3.7 \%$ & $17.7 \%$ & $4.5 \%$ \\
Lowland rice counties, South Carolina & $12.9 \%$ & $27.2 \%$ & $9.6 \%$ \\
& $-6.7 \%$ & $-1.5 \%$ & $7.2 \%$ \\
\hline
\end{tabular}

Sources: US Census, Agricultural Census. Upland cotton counties are those producing more than 1,000 bales of upland cotton at the beginning of the decade, except for 1829-39 for which only end-of-period cotton production data is available. Rice counties are those producing more than a million pounds of rice. The urban slave population of Charleston (Carter et al. 2006: Table Bb102) is excluded.

TABLE 4. Average number of slaves per slave owner, 1839-59

\begin{tabular}{lccc}
\hline & 1839 & 1849 & 1859 \\
\hline Total South & 8.84 & 8.90 & 8.94 \\
& $(0.60)$ & $(0.60)$ & $(0.62)$ \\
South Carolina & 13.98 & 14.47 & 14.90 \\
& $(0.62)$ & $(0.63)$ & $(0.63)$ \\
Upland cotton counties, SC & 12.18 & 13.74 & 14.67 \\
& $(0.58)$ & $(0.60)$ & $(0.60)$ \\
Other counties, SC & 15.90 & 15.13 & 15.08 \\
& $(0.68)$ & $(0.66)$ & $(0.66)$ \\
\hline
\end{tabular}

Gini coefficients in parenthesis. Source: US Census (slave schedules).

while the number of slaves per slave owner remained roughly stable for the South as a whole in the 1840s, it rose significantly in South Carolina. Moreover, all this increase is attributable to the increasing concentration of slave ownership in the upland cotton counties. While slave wealth remained more concentrated in other counties (due to the historically larger scale of rice plantations), their levels of concentration fell in the 1840s. In the upcountry, by contrast, plantations were becoming larger. This suggests that more successful planters in such regions were purchasing slaves from less successful planters resulting in both selection and scale effects on productivity.

To sum up, the approximate doubling of South Carolina's cotton output over the 1840 s could have been driven either by allocating more land and slaves to cotton or by increasing their productivity. To the extent that it was the latter it may have come about through transformations in the technology and organization of individual plantations,

ownership to a wider Southern population, and create more political support for the institution. This view was favorably quoted by the author of the "Inalienability of Slaves" (Anon. 1857), who additionally advocated that slaves be made inseparable from land, like medieval serfs. Needless to say, none of these proposals were realized. 
or through changes in composition and economies of scale resulting from concentration of slave and landownership. Although the existing evidence makes it difficult to weigh the relative contribution of these factors, for the purposes of this article it is not necessary to do so, for my hypothesis is consistent with all these mechanisms. As McDuffie suggests, it was their overhead of debts that likely convinced some planters to increase their specialization in the cash crop despite low prices. But it was those same debts, and the risk of foreclosure they entailed, that may have pressured slave owners to adopt the latest cost-reducing seeds and techniques from the Southwest. Finally, if some planters remained attached to their traditions, refusing to adapt to competition, foreclosure would have redistributed their slaves to more productive plantations and led to specialization and productivity growth nonetheless.

\section{Counterfactual Evidence from Kentucky}

If South Carolina's slave owners had not been subject to credit market discipline then my argument implies that cotton specialization and productivity growth would have been absent or subdued. One may test this claim by comparing South Carolina to states in which credit market discipline was relatively loosened. We saw in table 2 that South Carolina saw higher productivity growth in the 1840s than any cotton state apart from Tennessee. Yet the available data allows for no simple way to compare the degree of credit market discipline across these states. ${ }^{50}$ The most notorious form of debt relief in the 1840s consisted of Southwestern states defaulting on the bonds of state-backed "planter banks" created in the boom years (Baptist 2014: 291). However, these actions directly affected only a limited group of stockholders, and historians tend to find that foreclosure was also rampant on the Southwestern frontier in the 1840s (Kilbourne 1995; Murphy 2017).

A stronger contrast to South Carolina might be Kentucky, which also suffered as a result of Southwestern competition, but had a remarkable legacy of broad-based debt relief. Although some Kentucky planters moved into cotton in the 1830s when prices were high, Kentucky did not develop a full-blown cotton culture until after the Civil War. Kentucky plantations tended to be smaller and less reliant on short-term debts to merchants and factors. But Kentuckians were by no means free from debt, indeed their level of indebtedness proved a highly contentious political issue.

From 1816 to 1819 many Kentucky farmers had purchased land on credit, either on installments from government land offices, or through mortgages from local banks. With the panic of 1819 credit contracted and prices fell, increasing the burden of debt. In a remarkable episode, which foreshadowed the "lender of last resort" function of modern central banks, Kentucky farmers successfully lobbied the state to bail them out (Bodenhorn 2000: 44). The legislature passed laws allowing landowners to delay payments on their mortgages by up to two years. They also chartered the Bank of the

50. I have not yet been able to collect data on court sales for other states, but intend to do this in future comparative work. 
TABLE 5. Slave ownership and agricultural production in Kentucky

\begin{tabular}{lccc}
\hline & 1840 & 1850 & 1860 \\
\hline Number of slave owners & 32,457 & 38,832 & 40,305 \\
Number of slaves & 181,524 & 211,632 & 226,823 \\
Slaves per slave owner & 5.59 & 5.45 & 5.63 \\
& $(0.51)$ & $(0.50)$ & $(0.52)$ \\
Agricultural production (in tons): & & & \\
Cotton & 346 & 152 & 0 \\
Tobacco & 26,718 & 27,751 & 54,063 \\
Hemp & 8,736 & 17,787 & 35,065 \\
Corn & 19,924 & 29,336 & 32,022 \\
\hline
\end{tabular}

${ }^{*}$ Gini coefficients in parenthesis. Source: US Census (agricultural census and slave schedules). Conversion to tons: Table of Weights, Raymond and Ward, Chicago (c. 1854).

Commonwealth of Kentucky, whose primary mission was to relieve indebted farmers through an extension of easy credit. All Kentucky landowners were eligible for a $\$ 1,000$ loan from the bank, in irredeemable notes that were declared legal tender for the payment of taxes and debts. Many laws were subsequently passed to encourage creditors to accept these notes at par. ${ }^{51}$ The inflation this generated provided significant relief to Kentucky's debtors, while antagonizing creditors.

Although the Commonwealth Bank was effectively destroyed in the early 1830s by an elite coalition led by Henry Clay, Kentucky's radical debt-relief experiments of the 1820s helped shape the state's response to the post-1837 depression. In the early 1840 s, the legislature enacted several measures to ease the judicial and financial pressures on Kentucky debtors. They cancelled the middle term of the state's circuit court, restricted the instances in which magistrates could give judgments, exempted the slave property of married women from liability for their husband's debts, increased exemptions for domestic property, and instructed state banks to issue more notes and allow debtors more leeway in repayment (Jones 1971). As a result, indebted Kentucky slave owners were less threatened by foreclosure than slave owners in South Carolina.

This different experience of debt and foreclosure was accompanied by a markedly different pattern of allocating slave labor. Both Kentucky and South Carolina slave owners were threatened by competition from the Southwest from the 1830s on, and thereafter both were net exporters of slaves. ${ }^{52}$ But whereas South Carolina doubled its production of cotton in the 1840s, table 5 shows that the low prices of that decade

51. Mathias 1973. Tennessee set up a similar bank in 1819, the State Bank of Tennessee, with a mandate to lend to landowners at a maximum of \$500 in inconvertible notes (Abernethy 1927).

52. Kentucky's net export of slaves was slightly lower as a percentage of its slave population, 11 percent rather than 14 percent (Tadman 1996: 12). 
cut Kentucky's small cotton culture in half. ${ }^{53}$ And while the average number of slaves per slave owner rose in South Carolina in the 1840s, in Kentucky it fell.

Of course, cotton was new to Kentucky, and it was harder to grow and transport for reasons of soil and geography. Tobacco, however, had long flourished in Kentucky, so one might expect slave owners to have switched to tobacco when cotton proved unprofitable at the lower price. However, tobacco prices also fell in the 1840s, and Kentucky planters struggled to compete with the more developed tobacco culture of Virginia and North Carolina. With cotton almost eradicated and tobacco stagnating, the expansion of Louisville's hemp industry did stimulate a flow of slaves into hemp production and manufacturing. However, Kentucky's main response to low staple prices in the 1840 s was to shift to corn and other food crops. These crops guaranteed farmers' subsistence when markets failed but provided little opportunity for expanding production by means of export or economies of scale. ${ }^{54}$ It may thus help to explain the falling concentration of slave ownership in these years. In fact, the 1840s saw agriculture in many parts of the state settle on a distinctive pattern of small-scale farming - orientated toward local markets when it was orientated toward markets at all—that would extend into the twentieth century (Hopkins 1951; Pudup 1990).

While debt enforcement in South Carolina was associated with increased market specialization, a growing concentration of slave ownership, and agricultural innovation, debt relief in Kentucky was associated with a withdrawal to the security of subsistence crops and a deconcentration of slave ownership. Urban manufacturers in Kentucky were to some extent able to take advantage of the stagnation in agriculture by bidding slaves away from plantations. ${ }^{55}$ However, competition with both manufacturing and the Southwest was muted by debt relief, allowing slave owners to weather the storm, much as historians have (wrongly) imagined they did in South Carolina.

Why did South Carolina not pass any of the debt-relief measures we saw in Kentucky and other states? We know that there were murmurings in support of such measures from indebted South Carolina planters, including a proposal to establish a bank similar to the Commonwealth Bank of Kentucky, but these faced a united opposition among the state's political elite. ${ }^{56}$ Ultimately South Carolina passed procreditor

53. Anon. (1863) claims that Kentucky's cotton culture was entirely wiped out in the 1840s, and that "for several years subsequent to the year 1840 the cultivation of cotton was almost wholly given up in the State of Tennessee," although Watkins (1908: 256) indicates only a slight decline.

54. Apart from a tiny route from Lexington to Frankfort, Kentucky did not build any railroads before the 1850 s.

55. On the use of slaves in Kentucky's hemp and tobacco manufacturing see Hopkins (1951). South Carolina also saw manufacturing growth in the 1840s, but most of the cotton and lumber mills employed only wage labor. Thus, the slave population of Louisville increased by 43 percent from 1840 to 1850 , while that of Charleston decreased (Carter et al. 2006: table Bb99-128).

56. Smith 1958: 204; State Agricultural Society 1846: 105. In his address of 1844, Hammond proposed exempting land (but not slaves) from execution for debts other than those contracted to purchase the land. However, this was never discussed in the legislature. In the early 1850 s South Carolina did belatedly follow other Southern states in issuing a homestead exemption law allowing debtors to shield some of their real property from creditors. However, this protection was not extended to slave property, and uniquely among 
legislation in the early 1840s, increasing the penalties for insolvent debtors (Richardson 1851: 14). The reason, I suspect, is twofold.

First, South Carolina debtors may have had less opportunity to benefit from the debt-relief measures carried out in Kentucky. Their direct dealings with international cotton factors meant they were typically paid in sterling bills. Because cotton prices were determined in British exchanges, and debts needed to be convertible to New York or British money, an expansion of bank credit money would just increase the price of local goods in terms of cotton. Whitfield Brooks, a founder of the State Agricultural Society, explained that "the planter of cotton is forced to sell his produce at a price regulated by gold and silver and to purchase every article of consumption by a paper standard in the domestic market" (State Agricultural Society 1846: 22). This meant that the debts of South Carolina planters were less susceptible to being inflated away in the manner achieved in Kentucky. Indeed, having suffered from domestic inflation in the 1830s, South Carolina planters were more wont to censure banks for their irresponsible paper issuance in the upturn than to look to the same for salvation in the downturn. ${ }^{57}$

Second, South Carolina's debtors were unable to form a coherent political opposition. Historians typically attribute the lack of party polarization in South Carolina to the appeal of sectionalism. However, scholars have recently argued that this sectional unity was largely premised on the ability of low-country slave owners to extend slave ownership to the piedmont, partly by extending credit to an emergent upcountry elite (King and Moeller 2006: 5-11; Klein 1992). The latter in turn became local creditors who could be counted on to oppose debt-relief legislation. The spread of slavery also reduced the influence of a non-slave-owning yeoman class with which indebted slave owners could make common cause. Thus, a regional and class alliance around the issue of debt relief was never able to gain political traction. In Kentucky, by contrast, credit was typically provided by state banks situated in Louisville, the Bank of the United States, or the federal government in the case of land office loans. It was much easier for indebted slave owners and yeomen to rally a local electorate in opposition to such a distant set of creditors.

\section{Conclusion}

We began with the paradox that cotton seemed unprofitable beneath 8 cents a pound for most South Carolina planters in 1841, and yet they nonetheless produced more

Southern states, South Carolina revoked their homestead exemption law in 1858, over concerns that it restricted the flow of credit.

57. Brooks argued for currency reforms that would put an end to the "derangement of the currency," which is "always fluctuating with the expansions and contraction of bank issues" (State Agricultural Society 1846: 22) and other members of the State Agricultural Society called for laws curtailing bank lending and note issuance (ibid.: 20, 23, 105-9). 
cotton over the following years, even as the price fell. ${ }^{58}$ We now have a two-part explanation for that paradox. In the first instance, they had to plant cotton to repay debts contracted during the boom years. In the second instance, they made cotton profitable at the lower price, by reaping economies of scale and introducing new seeds and techniques. ${ }^{59}$ This was a modern, capitalist response to changing price signals, not the response of a patrician elite. If South Carolina's planters liked to see themselves in the image of the latter, their behavior revealed that other forces were at work.

I have argued that a key force guiding this reaction was the threat and reality of foreclosure, which shaped aggregate patterns of growth and compelled debtors to adapt their behavior. Yet I do not wish to imply that capitalist dynamics are simply the result of creditors lording it over debtors. The belief that creditors were "the power behind the throne" of King Cotton (Stone 1915: 562) was common among planters, who liked to blame creditors for many things, including the widespread practice of separating slave families through sale. Yet this view conveniently ignores the fact that many creditors were themselves planters. ${ }^{60}$

In fact, the pecuniary interests of creditor and debtor were often aligned: Both bore the risk of crop or market failure (especially if collateral was posted) and both benefited when returns were high. Planter-creditors may have been motivated to lend by a desire for security, for if their crops failed they could potentially reap from their paper assets. Thus, it would be a mistake to assume that creditors simply imposed their own profit-maximizing preferences on a risk-averse planter class. Yet whatever the mind-set of creditors, an expanding credit economy would still enforce market specialization, for debtors would still have to generate enough cash at current market prices to repay their debts. The point is that a widespread dependency on credit generates structural compulsions of its own, supervening on the ex-ante motivations of individual slave owners.

This observation allows us to relate our findings to a long-standing debate about the relation between slavery and capitalism. This debate has tended to follow Max Weber in identifying capitalism with a "spirit" or "mentality" —one of thrift, rationality, and progress. Thus Genovese, in his argument that slavery was "noncapitalist,"

58. Hammond did not repeat his calculations, but General Hamilton, addressing an agricultural society in 1844 , claimed that the price of cotton was then below the cost of production, and that the planters could not grow it for " 4 cents net [of current costs] at the present price of negroes" (Watkins 1908: 80).

59. The spread of railroads may also have played a role in this regard. In 1833, South Carolina constructed the first railroad in the South, from Charleston to Hamburg. This was extended to Columbia in 1842, and to several branch lines in the following years (Majewski 2011). Cheaper transportation may have reduced costs for the planter and enabled the spread of cotton cultivation (Smith 1958: 156, 192). By opening the best lands on the frontier, railroads may also have increased average yields, and by cheapening food imports they may have encouraged cotton specialization. The same competitive pressures that drove other forms of innovation may also have been behind railroad construction. In contrast to the North, where railroad construction was largely private, South Carolina's railroads were almost all state funded. To overcome opposition in the legislature from coastal and river-valley planters who did not individually stand to gain, railroad boosters often drew on fears of Southwestern competition (ibid.: 192, 156-57).

60. Martin (2010: 846) finds that the majority (81 percent) of creditors in South Carolina were local individuals not listed as merchants. Given the distribution of wealth in South Carolina we can assume most of them were slave owners. 
pointed to "paternalist" relations between master and slave, and to the "prebourgeois" culture of the master class. By contrast, Fogel and Engerman contended that slave owners were in fact calculating and modernizing. However, if the debt constraint I am describing was operative, then identifiably capitalist outcomes-market orientation, profit maximizing, technical innovation-are in an important sense independent of mentality. This is because slave owners who were not interested in specializing for the market, maximizing profit or adopting cost-reducing innovations would end up losing their slaves to those who were. On this view, capitalist patterns of behavior can be the unintended consequence of competitive selection operating via credit markets.

My argument is consistent with recent historiography that has emphasized the pressures of debt in driving the transition to capitalist agriculture in the North (Levy 2012; Post 2011). I have identified similar dynamics operating in the antebellum South. North and South were marked by very different social and economic structures, but agriculture in both regions was characterized by comparatively high levels of debt and a legal system that enforced creditor claims through compulsory foreclosure. Thus, in both regions, credit market discipline may have led to capitalist development—in the form of market specialization and high levels of productivity growth. ${ }^{61}$

Can this claim be generalized to other places and times? The colonies of British America were peculiar in developing a legal system that favored foreclosure over punishment for insolvent debtors, and removed impediments to the sale or transfer of assets to repay creditors. By contrast, productivity growth appears to have been slower or nonexistent in other New World slave economies, where courts were often less favorable to creditors. For instance, in the sugar-exporting region of Northeastern Brazil, land and slaves were legally protected from seizure for the repayment of debt (Price 1991: 305; Schwartz 2004: 187), while productivity there appears to have stagnated from the mid-eighteenth century onward (Klein and Luna 2009: 34). Further studies will be necessary to establish whether the rise of capitalism coincided with the imposition of credit market discipline in other parts of the world.

\section{Appendix}

\section{Revised Estimates of South Carolina's Slave Trade}

Several historians have attempted to estimate the scale of the slave trade in South Carolina. Michael Tadman derived decennial estimates of slave sales based on court sales from Charleston and demographic estimates of slave exports (1996: 119-20). Steven Deyle (2005: 294) combined Tadman's figures with Russell's more comprehensive data on court sales, correcting Russell's own calculations of total sales (Russell 1993: 67-68). These authors find that both court-ordered sales and slave exports were lower in the depressed 1840s than in the booming

61. While the literature on "the market revolution" has tended to overlook the South (Egerton 1996; Stokes and Conway 1996), the effect of credit market discipline may have been magnified in that region simply because the slave owners on whom such pressures operated tended to control more resources (both economic and political), and thus have more influence over regionwide patterns of development, than the small farmers of the North. 
1850s, suggesting that the foreclosure crisis had little impact on the slave trade. ${ }^{62}$ Yet their methods underestimate the number of court sales in the 1840s, as well as the number of court sales to slave traders.

Tadman tends to downplay the role of slave traders in court sales. He argues that slave traders preferred private to auction sales because they liked to pay in cash, and to buy individual slaves rather than the "mixed lots" available at auction (Tadman 1996: 52-55, 113, 136). Russell points out several flaws in Tadman's argument, but shares his view that slave traders were wary of court auctions. ${ }^{63}$ For Russell the problem was that court auctions were not competitive because auctioneers may have favored debtors and locals over creditors and outsiders (Russell 1993: 100-1). Thus, both authors would presumably be skeptical of the argument, made in the preceding text, that debt and foreclosure contributed to productivity growth through reallocating slave labor to more cost-efficient producers.

However, according to Tadman's own estimates for the 1850s a third of all slaves sold outside the state were purchased at court sales, hardly a small amount (Tadman 1996: 119-20). Tadman claims that court sales in the 1840s were of little significance, but Russell (1993: 73) and Deyle (2005: 294) both find that there were more court sales than noncourt sales in that decade. They estimate court sales as a fixed percentage of the total slave population in each decade, a percentage derived from Russell's average for 1820 to 1860 (.85 percent per year). But Russell's own figures indicate that the percentage of slaves sold through the courts doubled in the 1840s. ${ }^{64}$ Combining my own data on court sales with Russell's, in table 1 I estimate the number of court sales in each decade separately. As a result, the 1840s is revealed as the peak decade for foreclosures, with 10,680 sold by South Carolina's courts, and more than half of all slave sales taking place at court auction. ${ }^{65}$ If we follow Tadman's assumption that 20 percent of court sales went to slave traders then such sales accounted for almost half of the interstate trade from South Carolina in the 1840s.

Another potential problem with the estimates of these authors is that they all assume a fixed proportion of slave exports were sold rather than transported with migrating planters. ${ }^{66}$ Richard H. Steckel and Nicolas Ziebarth (2013) have recently collected new data on the coastal trade that allow us to construct more precise decennial estimates of this proportion. Figure 9

62. Deyle 2005: 295. It should be noted that in his broader argument Deyle, unlike Russell and Tadman, does not downplay the importance of court sales in the slave trade. However, his reliance on Tadman and Russell's figures lead Deyle to underestimate the impact of court sales in the 1840s.

63. Russell (1993: 67-68) points out that Tadman's claim that slave traders repudiated purchasing on credit is not consistent with his own evidence of highly leveraged slave-trader accounts. Moreover, only equity and probate sales were in credit, the medium of exchange in sheriff's sales being cash. Finally, if slave traders preferred to purchase individual slaves rather than "mixed lots" they should have concentrated their buying at auctions, for Russell presents evidence that more slaves were sold individually through auction than private sales.

64. From .6 percent in the 1830 s, to 1.1 percent per annum in the 1840 s (authors' calculations from Russell 1993: Appendix).

65. Combining my court sale data with Russell's, I estimate that 1.15 percent of South Carolina's slaves were sold through courts each year in the 1840s. Adjusting Deyle's overall estimates using this figure the estimate of slaves sold through the courts increases by 35 percent, the estimate of total sales per year in that decade increases from 1.6 to 2 percent of the slave population, and the estimate of the percentage of the interstate trade coming from court sales increases from 35 to 46 percent. Note, however, that the latter figure is likely still an underestimate, for it relies on Tadman's assumption that only 20 percent of court sales went to the interstate traders, and ignores resales to the interstate trade by local traders.

66. Tadman, Russell, and Deyle all derive their estimates of total slave exports from demographic changes (using Tadman's survivor analysis) and assume that 60 percent of slave exports were through the slave trade, the rest going through migrating planters. 
2500

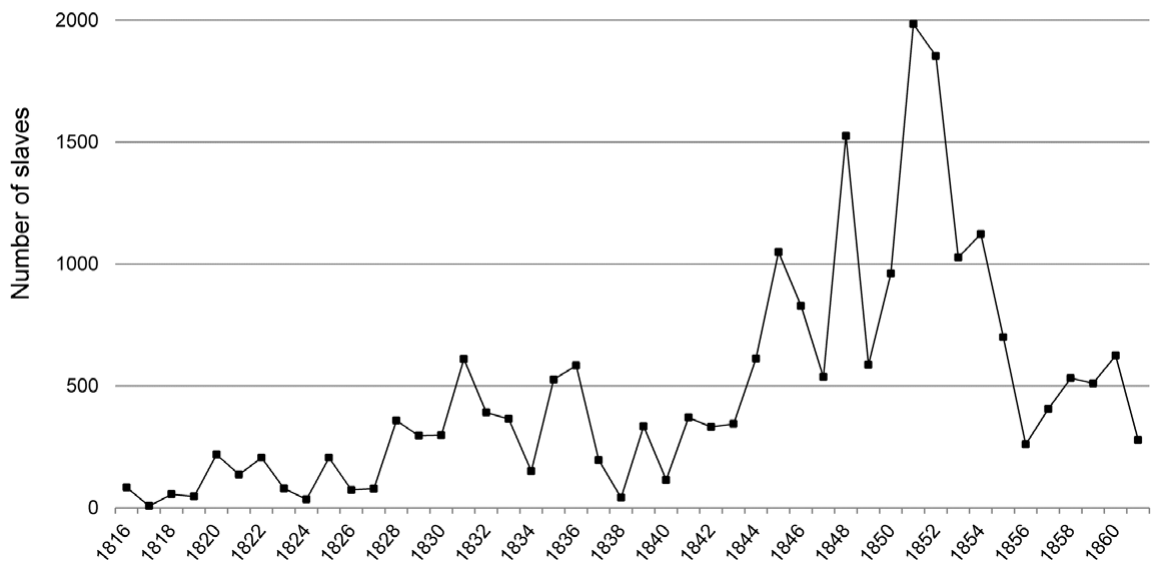

FIGURE 9. Number of slaves shipped from Charleston to other US ports. Source: Ship manifests courtesy of Richard Steckel.

displays the number of coastal slave exports from Charleston from 1816 to 1861 . While this figure excludes the overland trade, it casts doubt on Tadman's finding (1996: 12) that fewer slaves were exported in the 1840s than in other decades. It indicates that 20 times as many slaves were shipped from South Carolina during the 1840s as in the 1830s, and seven times as many as in the 1850s. Using a combination of estimating procedures, Steckel and Ziebarth find that the proportion of these slaves shipped by traders was at its highest in the 1840s. ${ }^{67}$

Figure 9 may also be compared to figure 4, for both show a sharp break in 1845, at which point both the number of foreclosures and the number of slaves shipped from South Carolina doubled.$^{68}$ It is hard to account for the latter by any shift in the preference of interstate slave traders toward coastal shipping rather than inland routes, for the 1840s was a decade in which other forms of transportation (canals and railroads) were on the rise. Yet the correlation is consistent with the hypothesis that many of the slaves sold at public auction ended up in the interstate trade.

\section{References}

Abernethy, Thomas P. (1927) "The early development of commerce and banking in Tennessee." The Mississippi Valley Historical Review 14 (3): 311-25.

67. Steckel and Ziebarth (2013: 804, table 8) find this proportion to have been 61 percent in the 1840s, compared to 48 percent in the 1830 s, and 57 percent in the 1850 s.

68. The average for the ten years prior to 1845 is 346 , the average for the ten years after is more than three times that amount: 1,148 . 
Anderson, Ralph, and Robert Gallman (1977) "Slaves as fixed capital: Slave labor and Southern economic development." The Journal of American History 64 (1): 24-46.

Anon. (1857) "Inalienability of slaves.” De Bow's Review 13.

(1863) "The cultivation of cotton." The New York Times, March 17.

Baptist, Edward (2014) The Half Has Never Been Told: Slavery and the Making of American Capitalism. New York: Basic Books.

Barnes, Diane L., Brian Schoen, and Frank Towers, eds. (2011) The Old South's Modern Worlds: Slavery, Region, and Nation in the Age of Progress. Oxford: Oxford University Press.

Beckert, Sven, and Seth Rockman, eds. (2016) Slavery's Capitalism: A New History of American Economic Development. Philadelphia: University of Pennsylvania Press.

Blackmar, Elizabeth (2012) "Inheriting property and debt: From family security to corporate accumulation," in Michael Zakim and Gary Kornblith (eds.) Capitalism Takes Command: The Social Transformation of Nineteenth-Century America. Chicago: University of Chicago Press: 93-118.

Bodenhorn, Howard (2000) A History of Banking in Antebellum America: Financial Markets and Economic Development in an Era of Nation-Building. Cambridge: Cambridge University Press.

Brenner, Robert (2007) "Property and progress: Where Adam Smith went wrong," in Chris Wickham (ed.) Marxist History-Writing for the Twenty-First Century. Oxford: Oxford University Press: 49-111.

Broadberry, Stephen, Bruce Campbell, and Bas Van Leeuwen (2011) "The sectoral distribution of the labour force and labour productivity in Britain, 1381-1851." Quantifying Long Run Economic Development, Venice workshop.

Cairnes, John E. (1862) The Slave Power: Its Character, Career and Probable Designs. London: Parker, Son, and Bourn.

Carter, Susan B., Scott S. Gartner, Michael R. Haines, Alan L. Olmstead, Richard Sutch, and Gavin Wright, eds. (2006) Historical Statistics of the United States: Millennial Edition Online. New York: Cambridge University Press.

Census of Charleston (1848) Census of the city of Charleston, South Carolina, for the year 1848, exhibiting the condition and prospects of the city, illustrated by many statistical details, prepared under the authority of the City council by J. L. Dawson and H. W. De Saussure. Charleston, S.C.: J. B. Nixon, printer, 1849.

Clark, Washington A. (1922) The History of the Banking Institutions Organized in South Carolina Prior to 1860. Columbia: Historical Commission of South Carolina.

Clegg, John J. (2015) “Capitalism and slavery.” Critical Historical Studies 2 (2): 281-304.

Coclanis, Peter (1989) The Shadow of a Dream: Economic Life and Death in the South Carolina Low Country, 1670-1920. Oxford: Oxford University Press.

Conrad, Alfred H., and John R. Meyer (1958) "The economics of slavery in the ante bellum South." The Journal of Political Economy 66 (2): 95-130.

Craig, Lee A., and Thomas Weiss (1998) Rural Agricultural Workforce by County, 1800 to 1900. [machinereadable dataset] Oxford, OH: EH.Net, Miami University [distributor]. eh.net/databases/agriculture/ (accessed August 1, 2017)

Deyle, Steven (2005) Carry Me Back: The Domestic Slave Trade in American Life. Oxford: Oxford University Press.

Easterlin, Richard A. (1960) "Interregional differences in per capita income, population, and total income: 1840-1950," in National Bureau of Economic Research (ed.) Conference on Research in Income and Wealth: Trends in the American Economy in the Nineteenth Century. Princeton, NJ: Studies in Income and Wealth 24: 73-140.

Egerton, Douglas R. (1996) "Markets without a market revolution: Southern planters and capitalism." Journal of the Early Republic 16 (2): 207-21.

Egnal, Marc (1998) New World Economies: The Growth of the Thirteen Colonies and Early Canada. Oxford: Oxford University Press.

Engerman, Stanley L. (1967) "The effects of slavery upon the southern economy: A review of the recent debate." Explorations in Entrepreneurial History 4 (2): 71-97.

Faust, Drew G. (1985) James Henry Hammond and the Old South: A Design for Mastery. Baton Rouge: Louisiana State University Press. 
Fisher, Irving (1933) "The debt-deflation theory of Great Depressions." Econometrica 1 (4): 337-57.

Fleisig, Heywood (1965) "Mechanizing the cotton harvest in the nineteenth-century South." Journal of Economic History 25 (4): 704-6.

Fogel, Robert W., and Stanley L. Engerman (1975) Time on the Cross: The Economics of American Negro Slavery. New York: W. W. Norton and Company.

Follett, Richard (2000) The Sugar Masters: Planters and Slaves in Louisiana's Cane World, 1820-1860. Baton Rouge: Louisiana State University Press.

Genovese, Eugene D. (1965) The Political Economy of Slavery: Studies in the Economy and Society of the Slave South. New York: Pantheon Books.

Gray, Lewis C. (1933) History of Agriculture in the Southern United States to 1860. Washington, DC: The Carnegie institution of Washington.

Hammond, James H. (1841) Anniversary oration of the State Agricultural Society of South Carolina. Columbia, SC: A. S. Johnston.

Hancock, David (1994) "“Capital and credit with approved security': Financial markets in Montserrat and South Carolina, 1748-1775." Business and Economic History 23 (2): 61-84.

Hopkins, James F. (1951) A History of the Hemp Industry in Kentucky. Lexington: University Press of Kentucky.

- (2013) River of Dark Dreams. Cambridge, MA: Harvard University Press.

Jones, Thomas B. (1971) "New thoughts on an old theme." The Register of the Kentucky Historical Society 69 (4): 293-312.

Kilbourne, Richard (1995) Debt, Investment, Slaves: Credit Relations in East Feliciana Parish, Louisiana, 1825-1885. Tuscaloosa: University of Alabama Press.

- (2006) Slave Agriculture and Financial Markets in Antebellum America: The Bank of the United States in Mississippi, 1831-1852. London: Taylor and Francis.

King, Ron, and Justin Moeller (2006) "Party politics and the popular franchise: Removal of the property qualification and the democratization of America." Paper presented at the Western Political Science Association, Albuquerque.

Klein, Herbert S., and Francisco V. Luna (2009) Slavery in Brazil. New York: Cambridge University Press.

Klein, Rachel N. (1992) Unification of a Slave State: The Rise of the Planter Class in the South Carolina Backcountry, 1760-1808. Chapel Hill: University of North Carolina Press.

Knodell, Jane (2006) "Rethinking the Jacksonian economy: The impact of the 1832 bank veto on commercial banking." The Journal of Economic History 66 (3): 541-74.

Levy, Jonathan (2012) "The mortgage worked the hardest: The fate of landed independence in nineteenth century America," in Michael Zakim and Gary Kornblith (eds.) Capitalism Takes Command: The Social Transformation of Nineteenth-Century America. Chicago: University of Chicago Press: $39-68$.

Lindert, Peter, and Jeffrey Williamson (2016) Unequal Gains: American Growth and Inequality Since 1700. Princeton, NJ: Princeton University Press.

Majewski, John (2011) Modernizing a Slave Economy: The Economic Vision of the Confederate Nation. Chapel Hill: University of North Carolina Press.

Mann, Bruce H. (2002) Republic of Debtors: Bankruptcy in the Age of American Independence. Cambridge, MA: Harvard University Press.

Margo, Robert (2000) Wages and Labor Markets in the United States, 1820-1860. Chicago: University of Chicago Press.

Martin, Bonnie (2010) "Slavery's invisible engine: Mortgaging human property." The Journal of Southern History 76 (4): 817-66.

- (2016) "Neighbor-to-Neighbor capitalism: Local credit networks and the mortgaging of slaves," in Sven Beckert and Seth Rockman (eds.) Slavery's Capitalism: A New History of American Economic Development. Philadelphia: University of Pennsylvania Press: 107-21.

Mathias, Frank F. (1973) "The relief and court struggle: Half-way house to Populism." The Register of the Kentucky Historical Society 71 (2): 154-76. 
Mehrling, Perry (1999) “The Vision of Hyman P. Minsky.” Journal of Economic Behavior \& Organization 39: $129-158$.

Menard, Russel R. (1994) "Financing the lowcountry export boom: Capital and growth in early South Carolina." The William and Mary Quarterly, 3rd series, 51 (40): 659-76.

Minsky, Hyman (1954) "Induced investment and business cycles." PhD diss., Department of Economics, Harvard University.

Murphy, Sharron A. (2017) "Banking on slavery in the antebellum South." Working paper presented to the Yale University Economic History Workshop May 1, New Haven, CT.

Niles, Hezekiah (1822) “Cultivation of cotton.” Niles' Weekly Register 23 (586), December 7.

North, Douglass C. (1966) The Economic Growth of the United States: 1790-1860. New York: Norton.

Olmstead, Alan L., and Paul W. Rhode (2008) "Biological innovation and productivity growth in the antebellum cotton economy." NBER Working Paper 14142.

(2010) "Productivity growth and the regional dynamics of antebellum southern development." NBER Working Paper 16494.

- (2016) "Cotton, slavery, and the new history of capitalism." Working paper, presented to the Law and Economics Workshop, Columbia Law School, October.

Ozanne, Adam (1999) "Perverse supply response in peasant agriculture: A review." Oxford Agrarian Studies 27 (2): 251-70.

Parker, William N., and Judith L. V. Klein (1966) "Productivity growth in grain production in the United States, 1840-60 and 1900-10," in D. S. Brady (ed.) Output, Employment, and Productivity in the United States after 1800. NBER: Princeton: Princeton University Press: 523-82.

Patent Office (1841) Report of the Commissioner of Patents for the Year 1841. House executive doc. 74, 27th Cong., 2d sess.

(1850) Report of the Commissioner of Patents for the Year 1850, part 2. House executive doc. 32, 31st Cong., 2d sess.

Phillips, Ullrich B. (1918) American Negro Slavery. New York: D. Appleton.

Porcher, Richard D., and Sarah Fick (2005) The Story of Sea Island Cotton. Layton, UT: Gibbs Smith.

Post, Charles (2011) The American Road to Capitalism: Studies in Class-Structure, Economic Development, and Political Conflict, 1620-1877. Leiden, The Netherlands: Brill.

Price, Jacob M. (1991) "Credit in the slave trade and plantation economies," in Barbara Solow (ed.) Slavery and the Rise of the Atlantic System. New York: Cambridge University Press: 293-340.

(1992) Perry of London: A Family and a Firm on the Seaborne Frontier, 1615-1753. Cambridge, MA: Harvard University Press.

Priest, Claire (2006) "Creating an American property law: Alienability and its limits in American history." Harvard Law Review 120 (20): 385-459.

(2015) "The end of entail: Information, Institutions, and slavery in the american revolutionary period." Law and History Review 33 (2): 277-320.

Pudup, M. B. (1990) "The limits of subsistence: Agriculture and industry in Central Appalachia.” Agricultural History 64 (1): 61-89.

RealtyTrac (2010) 2010 Year-End and Q4 Foreclosure Sales Report. www.realtytrac.com/news/ realtytrac-reports/2010-year-end-and-q4-foreclosure-sales-report/ (accessed August 1, 2017).

Richardson, J. S. G. (1851) Reports of Cases at Law Argued and Determined in the Court of Appeals and Court of Errors of South Carolina, Vol. 4. Charleston, SC: Walker and Burke.

Rosentgarten, Theodore (1986) "The Southern Agriculturalist in an age of reform," in Michael O'Brien and David Moltke-Hansen (eds.) Intellectual Life in Antebellum Charleston. Knoxville: University of Tennessee Press: 279-294.

Russell, Thomas D. (1993) "Sale day in antebellum South Carolina: Slavery, law, economy, and courtsupervised sales." PhD diss., Stanford University.

Schwartz, Steven B. (2004) "A Commonwealth within Itself: The Early Brazilian Sugar Industry, 15501670," in Steven B. Schwartz (ed.) Tropical Babylons: Sugar and the Making of the Atlantic World, 1450-1680. Chapel Hill: University of North Carolina Press: 116-158. 
Smith Jr., Alfred G. (1958) Economic Readjustment of an Old Cotton State: South Carolina, 1820-1860. Columbia, SC: University of South Carolina Press.

State Agricultural Society of South Carolina (1846) Proceedings of the Agricultural Convention and of the State Agricultural Society of South Carolina. Columbia, SC: Summer and Carrol.

Steckel, Richard H., and Nicolas Ziebarth (2013) "A troublesome statistic: Traders and coastal shipments in the westward movement of slaves." The Journal of Economic History 73 (3): 791-808.

Stokes, Melvyn, and Stephen Conway, eds. (1996) The Market Revolution in America: Social, Political, and Religious Expressions, 1800-1880. Charlottesville: University Press of Virginia.

Stone, Alfred H. (1915) "The cotton factorage system of the southern states." The American Historical Review 20 (3): 557-65.

Story, Joseph (1833) Commentaries on the Constitution of the United States. Boston: Little, Brown and Company.

Tadman, Michael (1996) Speculators and Slaves: Masters, Traders, and Slaves in the Old South. Madison: University of Wisconsin Press.

Temin, Peter (1969) The Jacksonian Economy. New York: Norton.

The Southern Agriculturalist (1842) Charleston: A. E. Miller, http://www.worldcat.org/title/ southern-agriculturist/oclc/10249256.

Watkins, James L. (1908) King Cotton, A Historical and Statistical Review: 1790 to 1908. New York: James L. Watkins and Sons.

Weber, Warren E. (2011) Balance sheets for US Antebellum State Banks [machine-readable dataset]. Research Department, Federal Reserve Bank of Minneapolis, www.minneapolisfed.org/research/ economists/wewproj.html (accessed August 1, 2017).

Whartenby, Franklee G. (1977) Land and Labor Productivity in United States Cotton Production, 18001840. New York: Arno Press.

Woodman, Howard D. (1968) King Cotton and His Retainers: Financing and Marketing the Cotton Crop of the South, 1800-1925. Lexington: University of Kentucky Press.

Wright, Gavin (1978) The Political Economy of the Cotton South: Households, Markets, and Wealth in the Nineteenth Century. New York: W. W. Norton and Company.

(2006) Slavery and American Economic Development. Baton Rouge: Louisiana State University Press. 